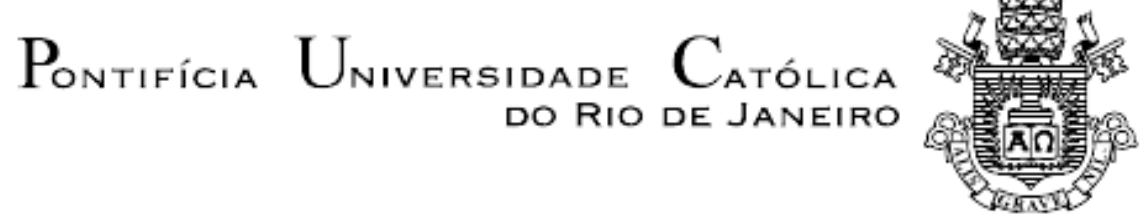

ANTONIA COSTA DE THUIN

\title{
Luandino e a língua como espaço de criação de utopia
}

Dissertação de Mestrado

Dissertação apresentada ao Programa de Pós-Graduação em Literatura, Cultura e Contemporaneidade da PUC-Rio como requisito parcial para obtenção do título de Mestre em Letras/Literatura, Cultura e Contemporaneidade.

Orientador: Prof. Alexandre Montaury Baptista Coutinho 
Pontifícia $U_{\text {Niversidade }}$ C $_{\text {atóllica }}$

ANTONIA COSTA DE THUIN

\section{Luandino e a língua como espaço de criação de utopia}

Dissertação apresentada como requisito parcial para obtenção do grau de Mestre pelo Programa de Pós-Graduação em Literatura, Cultura e Contemporaneidade do Departamento de Letras do Centro de Teologia e Ciências Humanas da PUCRio. Aprovada pela Comissão Examinadora abaixo assinada.

Prof. Alexandre Montaury Baptista Coutinho Orientador Departamento de Letras - PUC-Rio

Profa. Eneida Leal Cunha Departamento de Letras - PUC-Rio

Prof. Paulo Roberto Tonani do Patrocínio UFRJ

Profa. Denise Berruezo Portinari Coordenadora Setorial do Centro de Teologia e Ciências Humanas - PUC-Rio

Rio de Janeiro, 13 de abril de 2015. 
Todos os direitos reservados. É proibida a reprodução total ou parcial do trabalho sem autorização da universidade, da autora e do orientador.

\section{Antonia Costa de Thuin}

Graduou-se em Design pela ESDI-UERJ em 1997. Cursou pós-graduação em História da Arte pela PUC-Rio em 2002 e Interpretação de Conferências em 2010. Trabalha como tradutora e intérprete de inglês e francês. Continua sua pesquisa em literatura africana em seu doutorado na PUC-Rio.

Ficha Catalográfica

Thuin, Antonia Costa de

Luandino e a língua como espaço de criação de utopia / Antonia Costa de Thuin ; orientador: Alexandre Montaury Baptista Coutinho. - 2015. $73 \mathrm{f.}$; $30 \mathrm{~cm}$

Dissertação (mestrado)Pontifícia Universidade Católica do Rio de Janeiro, Departamento de Letras, 2015. Inclui bibliografia

1. Letras - Teses. 2. José Luandino Vieira. 3. Literatura em Angola. 4. Utopia. 5. Independência política e guerra. 6. Guimarães Rosa. I. Coutinho, Alexandre Montaury Baptista. II. Pontifícia Universidade Católica do Rio de Janeiro. Departamento de Letras. III. Título. 


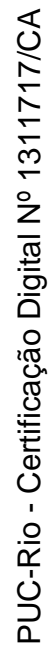

Para Nazareth Costa

Para Teresa Costa d'Amaral

Para Antonia Costa

Para o matriarcado 


\section{Agradecimentos}

Alexandre Montaury

Antonia Costa

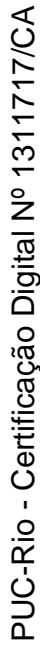

Daniele de Oliveira Cruz

Eneida Cunha

Paulo Roberto Tonani

Renato Cordeiro Gomes

Tatiana Guedes

Aos amigos

À família

À PUC-Rio

À CAPES

Ao $\mathrm{CNPq}$ 


\section{Resumo}

Thuin, Antonia Costa de; Coutinho, Alexandre Montaury Baptista. Luandino e a língua como espaço de criação de utopia. Rio de Janeiro, 2015. 73p. Dissertação de Mestrado - Departamento de Letras, Pontifícia Universidade Católica do Rio de Janeiro.

Esta dissertação se organiza a partir de três ensaios - A Língua como intraduzível, Os Rios que Comunicam e O Futuro do Pretérito - que focalizam questões relevantes na obra do escritor José Luandino Vieira. O objetivo é identificar, em alguns de seus livros, as formas com que a linguagem é trabalhada pelo autor em sua ficção, de modo a criar espaços de utopia política; dos tempos de luta pela independência angolana, na segunda metade do século $\mathrm{XX}$, às primeiras décadas do século XXI. Pretende-se mostrar ainda como sua busca por uma utopia permanece ao longo do tempo, não tendo cessado com o fim da guerra de independência nacional. A busca por justiça e por inclusão social materializamse como utopias, expressas sobretudo na linguagem adotada pelo escritor. No primeiro capítulo desta dissertação, discuto seu investimento na linguagem, e como isso é radical - no sentido de estar na raiz - de sua literatura e projeto de mundo. No segundo, falo mais amplamente como o rio - que flui e que segue, que some e volta a existir - é tema existente em Guimarães Rosa e Luandino, que seguem uma genealogia de criadores com a língua, mas que têm mais em comum do que ela. No terceiro, aprofundo-me nas questões políticas levantadas por seus textos e nas suas intenções.

\section{Palavras-chave}

José Luandino Vieira; Literatura em Angola; Utopia; Independência política e guerra; Guimarães Rosa. 


\section{Abstract}

Thuin, Antonia Costa de; Coutinho, Alexandre Montaury Baptista (Advisor). Luandino and language as a space to create utopia Rio de Janeiro, 2015. 73p. MSc. Dissertation - Departamento de Letras, Pontifícia Universidade Católica do Rio de Janeiro.

This thesis is organized from three essays - Language as untranslatable, Rivers that communicate and Future of the Past - that focus in relevant questions of the writer José Luandino Vieira work. The aim is to identify, in some of his books, how language is used by the author in his fiction, as a tool to create political utopian spaces; beginning during the time of fighting for Angola's independence, in the second half of the twentieth century, till the first decades of the twenty first century. It intends also to show how his search for utopia continues through time, and has not stopped with the end of the national independence war. The search for justice and social inclusion gain life as utopias, expressed above all in the language adopted by the author. In the first chapter of this dissertation, I talk about his investment in language and how is this crucial for his literature and his world Project. In the second, I talk more broadly about how the river - that comes and goes, disappears and reaches back to existence - is a subject presente in both, Guimarães Rosa and Luandino, following a genealogy of language creators, but with more in common than just that. In the third, I talk indepth about the political issues raised in his texts and his intentions

\section{Keywords}

José Luandino Vieira; Literature in Angola; Utopia; Independence politics and war; Guimarães Rosa. 


\section{Sumário}

$\begin{array}{ll}\text { 1. Introdução } & 9\end{array}$

2. A língua como intraduzível 23

2.1. Subversão e literatura menor 25

2.2. O espaço da tradução 30

2.3. Luandino e seu universo 32

3 Os rios que comunicam 38

3.1. Logótetas 40

3.2. Rios 42

3.3. O bando 46

$4 \quad$ O futuro do pretérito 52

4.1. Luandino e seus romances 52

4.2. Rancière e a história em Luandino 56

4.3. O sonho, o futuro, o "real" em Luandino 60

5. Conclusão 64

6. Referências bibliográficas 70 


\title{
Introdução
}

\author{
Nessa hora o trabalho tem de ser o mesmo: \\ derrubar outro cajueiro, e outro, e outro... \\ É assim o fio da vida \\ (José Luandino Vieira, Luuanda) \\ Também eu, sou um rio \\ (José Luandino Vieira, O Livro dos Rios)
}

Nesta dissertação, pretendo analisar questões da obra de José Luandino Vieira, para com isso identificar as formas com que a linguagem é por ele trabalhada em sua ficção, de modo a se posicionar politicamente ao longo do tempo. E também mostrar como sua busca por uma utopia para Angola, expressa na linguagem por ele adotada, permanece. Nas duas epígrafes apresentadas, temos trechos de dois textos de Luandino, distantes no tempo, mas com a mesma intenção: a de colocar a vida do seu protagonista, que se confunde com Angola, como eterna, fluida como um rio ou um galho de cajueiro.

A independência de Angola foi possível apenas após uma longa guerra, um processo lento e doloroso que durou treze anos. Mas, em paralelo ao combate armado, e mesmo antes dele, foi importante também a formação de discursos e ideias que deram forma a um projeto de nação. Como afirma Rita Chaves, "a história das Letras em Angola se mistura ostensivamente à história do país" (2005, p.20). Neste caso, o combate feito por angolanos, que eram filhos de portugueses e de quimbundos, o grupo étnico majoritário da região, mostra que, naquele momento, Angola se afirma como cultura autônoma em relação a Portugal, com problemas e soluções próprios.

A afirmação de uma língua é a afirmação cultural da identidade de uma nação, nação essa construída a partir da margem, a margem fora de Portugal, a margem dos musseques - que já então eram as regiões marginais, as favelas - de Luanda. Assim, a linguagem utilizada por José Luandino Vieira em seus textos pode ser vista como uma clara afirmação da independência de Angola, que dependia de uma narração de nação. A nação existe antes como imaginário do que 
como fato e lei, portanto criar e mostrar o cotidiano de um lugar, mostrar a sua diferença em relação à metrópole também era uma luta pela formação do país. $\mathrm{O}$ escritor, que sempre se colocou como um escritor das margens, utiliza a língua falada nos musseques de Luuanda, uma mistura do português com o quimbundo, que mostra a vida dos negros, mulatos e brancos pobres de uma Angola em formação.

Politicamente, os regimes coloniais sempre souberam da importância da unidade da língua em suas colônias. A língua portuguesa foi, portanto, usada como marco da colonização e do domínio português no espaço então caracterizado como o ultramar. O esgarçamento desse poder e a valorização das particularidades de Angola são produzidos no texto, com a inscrição de uma linguagem local, que reflete uma cultura que não é totalmente compreendida pela totalidade da nação colonizadora. Em seus textos, o autor encena a linguagem oral dos habitantes dos musseques, regiões periféricas de Luanda, que existem à margem da cultura portuguesa. $\mathrm{O}$ uso de estruturas de linguagem do quimbundo, língua nativa da região, é explicitamente defendido por ele, como dito em entrevista ao professor José Luís Pires Laranjeira, ao ser perguntado sobre o assunto em seu livro Luuanda:

\begin{abstract}
“A questão da linguagem já não é tão inocente assim... Muito embora não pretendesse fazer uma cópia fiel da linguagem utilizada pelas camadas populares luandenses." Tenho que reconhecer - para o caso do Luuanda - que em certa altura eu achei até que teria um significado político: demonstrar que, na própria língua do colonizador, a nossa diferença cultural nos permitia escrever de modo que era difícil, ao próprio colonizador, entender o nosso código linguístico. Mas essa parte deliberada na criação de uma linguagem é apenas uma excrescência. Porque o meu intuito era (não consegui, com certeza!) criar uma linguagem ao nível literário a partir dos mesmos processos e das estruturas linguísticas bantas da região de Luanda. Que fosse homóloga da linguagem popular e não a sua cópia ou a sua reprodução [...]. (Vieira, 1994)
\end{abstract}

Essa demarcação é clara e, do ponto de vista do regime colonial, subversiva. Carrega nela a intenção da utopia de uma nação: Angola. Entre os aspectos da formação de uma nação está a do domínio político da língua, que se apresenta, em Luuanda (o livro é composto por três novelas) como um fato já estabelecido. Cinquenta anos depois de escrever esse primeiro livro, numa trilogia - ainda inacabada - iniciada com O Livro dos Rios e continuada com O Livro dos 
Guerrilheiros, esse investimento na linguagem é elevado ao seu extremo, com frases mais rebuscadas, maior uso de regionalismos e neologismos e de construções narrativas não lineares, a esse uso da linguagem se soma o uso da história de Angola como parte integrante da narrativa. Esses três livros: Luuanda (1963), O Livro dos Rios (2006) e O Livro dos Guerrilheiros (2009) atuam como ponto de partida e de chegada dessa construção e delimitação de uma Angola literária, cada um com suas particularidades.

O que Luandino opera ao longo de toda a sua obra, mas começando com Luuanda, é uma literatura menor, nos termos em que Deleuze e Guattari a definem. Ao se apropriar da língua portuguesa, mas da língua portuguesa tal como era falada em Angola, não do padrão europeu oficial, da metrópole, e escrever com ela, o escritor opera uma desterritorialização da língua, tal como o conceito elaborado por Deleuze e Guattari, uma língua que apesar de ter sua origem de fala e seu local de emissão primeiro definidos em um espaço determinado, também é falada em outros territórios. Essa desterritorialização se faz possível a partir da apropriação da língua chamada maior, da língua utilizada pelo poder na região, e uma transformação dela, para que possa ter a exuberância de uma língua maior utilizada em prol da minoria (minoria aqui não numérica, mas em termos de hegemonia de poder). Como Deleuze, em Por uma Literatura Menor, afirma "a possibilidade de instaurar por dentro um exercício menor de uma língua mesmo maior [...] permite definir uma literatura popular, marginal, etc." (Deleuze e Guatarri, 1975). Somente a partir de dentro, essa literatura pode ser criada e a inversão pode ser feita, criando uma inversão de poder entre a língua da maioria e a variante utilizada pela minoria, que, pela via da linguagem, reafirma o caráter político do texto.

Deleuze e Guattari utilizam Kafka como o exemplo. Morando e escrevendo em uma República Tcheca ainda sob o jugo do Império Austro Húngaro, cuja língua oficial era o alemão - não o alemão oficial, no entanto -, Kafka escolheu para si o alemão simplificado, falado nas ruas de Praga, um alemão de negócios, encurtado, quando poderia, por exemplo, ter escolhido o yidish falado em família, por exemplo. Mas escolhe a desterritorialização do alemão, e sua apropriação, exatamente como explica Deleuze em seu abecedário, a longa entrevista dada para a televisão, sobre o conceito: 
A noção com pretensão nova é que não há território sem um vetor de saída do território e não há saída do território, ou seja, desterritorialização, sem, ao mesmo tempo, um esforço para se reterritorializar em outra parte. (Deleuze, [s.d])

Essa reterritorialização é que Kafka conseguiu operar a partir do alemão, e Luandino a partir do português. A língua deixa de ser a língua da cultura hegemônica simplesmente, também porque reterritorializada pela minoria. Ela é transformada e apropriada politicamente pela minoria, ao usar não o idioma idêntico ao que se faz ensinado pela metrópole, mas sim a variação dele, a sua capacidade de dominar a língua aparece, aparece a possibilidade de existência da minoria dentro do idioma a partir daí. Na primeira novela de seu livro Luuanda, Luandino começa a fazer esse uso da linguagem, a colocar o português falado em Angola como parte integrante de seu texto, como ferramenta de sua denúncia, como podemos ler abaixo:

Continuou abanando o fogo com raiva, a lenha já estava arder muito bem, cheia de estalos, fazendo mesmo pouco fumo, mas vavó não podia ficar ainda calada. Lamentou outra vez:

-- Aiuê!... Não te disse para ir no sô Souto? Cadavez se você ia lhe ajudar, ia nos fiar outra vez, cadavez quem sabe...

- O branco sô Souto, o branco sô Souto! Vê só, vavó, vê ainda, mira bem!

Zeca Santos estava tirar camisa amarela de desenhos de flores coloridas, essa camisa que tinha-lhe custado o último dinheiro e provocado uma grande maca com vavó. Na pouca luz da cubata e do dia sem sol, as costas estreitas de Zeca apareceram com um comprido risco vermelho atravessado. Vavó levantou com depressa e passou as mãos velhas e cheias de calo nas costas novas do neto.

- Aka! Como é que o menino arranjaste?... Diz só! Fal'então!?

Mas ele já tinha vestido outra vez a camisa. Virado para vavó Xíxi, empurrou-lhe devagar para ir no caixote dela e, sentando o comprido corpo magro na mesa pequena, começou a falar triste, disse:

-- Vavó me disseste para eu ir lá e eu fui. Verdade! Nem mesmo a chuva que tinha começado a chover e a fome estava-me chatear nessa hora... (Vieira, 2009, p.1516)

Luandino, aqui, coloca a dimensão social em seu texto. Zeca, rapaz negro na periferia de Luanda, não consegue trabalho, e nem sua avó acredita em sua palavra. Ao voltar para casa e pedir comida, é explicitada a situação de penúria em que se encontram. $\mathrm{O}$ texto assim é uma denúncia da situação social existente na então colônia. A essa dimensão de denúncia de uma situação de pobreza vivida pela população, se soma a utilização do idioma. Aqui ele é permeado por palavras como "maca", que não são habituais em Portugal. Ele faz uso, portanto, da 
variante local como forma de estabelecer diferenças. O português falado em Angola, com suas diferenças, é uma marca que não pode ser separada da história contada, e é uma marca política de afirmação de identidade também, ao reterritorializar o idioma fora de seu local de origem.

Assim, Deleuze afirma que a linguagem tem uma dimensão política quando utilizada e apropriada pela minoria, é uma forma de acionar o coletivo dessa minoria, e Luandino pode ser considerado um exemplo disso. Em certa medida, toda linguagem literária é política em si, como Rancière nos diz em A Partilha do Sensível:

Existe, portanto, na base da política, uma "estética" que não tem nada a ver com a "estetização da política" própria à "era das massas" de que fala Benjamin. Essa estética não deve ser entendida no sentido de uma captura perversa da política por uma vontade de arte, pelo pensamento do povo como obra de arte. Insistindo na analogia, pode-se entendê-la num sentido kantiano - eventualmente revisitado por Foucault - como o sistema das formas a priori determinando o que se dá a sentir. É um recorte dos tempos e dos espaços, do visível e do invisível, da palavra e do ruído que define ao mesmo tempo o lugar e o que está em jogo na política como forma de experiência. A política ocupa-se do que se vê e do que se pode dizer sobre o que é visto, de quem tem competência para ver e qualidade para dizer, das propriedades do espaço e dos possíveis do tempo. (Rancière, 2009, p. 16-17)

A política e a estética estão sempre imbricadas, elas fazem parte do regime de criação de discurso do homem, e delimitam também o posicionamento no espaço tempo. Há, portanto, uma dimensão política em qualquer expressão literária, na medida em que se decide o recorte desejado. A escrita, ao definir o que é lido, define seu espaço não só estético, mas também político.

Operando dessa forma, como afirmou o próprio Luandino na entrevista citada acima, tentando criar uma linguagem, Luandino trabalha com esse bilinguismo existente em Angola. Com a percepção de que existem duas línguas ${ }^{1}$, uma hegemônica, de poder, imposta pela metrópole - o português - , outra da minoria, da margem, a língua local - o quimbundo, ou antes, uma mistura do quimbundo com o português -, o escritor assume uma terceira, na sua desterritorialização, que o coloca à margem das outras duas. E assim coloca o seu texto como destinado apenas aos que querem se aventurar a compreendê-lo, aos

${ }^{1}$ LIENHARD, M. Situação Diglóssica e Narrativa Moderna em Angola. In: África, escritas literárias: Angola, Cabo Verde, Guiné-Bissau, Moçambique, São Tomé e Príncipe. Rio de Janeiro: Editora UFRJ/UEA, 2010. 
que querem tentar traduzi-lo. A língua que Luandino instrumentaliza em seus livros não é, portanto, parte da cultura portuguesa, ela é uma criação e uma afirmação da cultura angolana. E como tal deve ser percebida. A sua tradução cultural precisaria levar em conta o lugar de enunciação. O que interessa aqui não é apenas o que se fala, mas também a posição de quem fala. Luandino não fala aqui na condição de português, se coloca como angolano, como subalterno, pois colônia, periferia, etc. O Estatuto dos Indígenas Portugueses das Províncias da Guiné, Angola e Moçambique ${ }^{2}$ deixa claro que o indígena, ao fazer o uso correto da língua portuguesa, perde o seu status de inferior juridicamente. O parâmetro do correto é o português europeu, falado em Portugal, aprendido na escola, o que reforça a categoria de assimilado atribuída a eles. Foram assimilados e assimilaram a cultura do colonizador, e assim, em tese, poderiam usufruir de alguns dos direitos reservados aos cidadãos portugueses - apesar do caráter transitório dessa assimilação, que pode ser revogada em alguns casos. As condições para a conquista da cidadania eram:

\section{ESTATUTO DOS INDÍGENAS PORTUGUESES DAS PROVÍNCIAS DA GUINE, ANGOLA E MOÇAMBIQUE}

DECRETO-LEI No 39.666 - 1954 - Agência Geral do Ultramar

A Lei ·orgânica do Ultramar (Lei 11.0 2.066, de 27 de Julho de 1953) contém vários preceitos relativos a populações indígenas das províncias da Guiné, Angola e Moçambique.

Além das bases componentes da secção especialmente epigrafada "Das populações indígenas", encontram-se, nomeadamente, o n. ${ }^{\circ} \mathrm{V}$ da base LXV, sobre o julgamento das questões gentílicas, e o $\mathrm{n}^{\circ} \mathrm{V}$ da base LXIX, sobre a extensão dos sistemas penal e penitenciário.

$[\ldots]$

Deseja-se acentuar ter havido agora a preocupação de, sem enfraquecer a proteção legal dispensada ao indígena, considerar situações especiais em que ele pode encontrar-se no caminho da civilização, para que o Estado tem o dever de o impelir.

Nestes termos:

Usando da faculdade conferida pela $1^{\text {a }}$ parte do $\mathrm{n}^{\mathrm{o}} 2$ do artigo 109 o da Constituição, o Governo decreta e eu promulgo, para valer como lei, o seguinte:

Art. 56. Pode perder a condição de indígena e adquirir a cidadania o indivíduo que

\footnotetext{
${ }^{2}$ Estatuto dos Indígenas Portugueses das Províncias da Guine, Angola e Moçambique visto em 14/03/2015, http://disruptiva.net/nodes/view/29.
} 
prove satisfazer cumulativamente os requisitos seguintes:

a) - Ter mais de 18 anos.

b) - Falar corretamente a língua portuguesa.

c) Exercer profissão, arte ou ofício de que aufira rendimento necessário para o sustento próprio e da família a seu cargo ou possuir bens suficientes para o mesmo fim.

d) Ter bom comportamento e ter adquirido a ilustração e os hábitos pressupostos para a integral aplicação do direito público e privado dos cidadãos portugueses.

e) Não ter sido refratário ao serviço militar nem dado como desertor.

$\S 1$ A prova dos fatos referidos no corpo deste artigo far-se-á pelas normas previstas nas leis mas os requisitos das alíneas b), c) e d) podem também provar-se por certificados dos administradores dos concelhos ou circunscrições onde o indivíduo tenha residido nos últimos três anos.

Segundo João Paulo Borges Coelho,

A estratégia colonial decorreu de uma visão dicotómica segundo a qual todos os Africanos eram potenciais "terroristas", e a única forma de impedir esse seu "devir" era conquistá-los e comprometê-los activamente na defesa da ordem colonial. A nível ideológico, esta visão era suportada quer pelo mito imperial, com a sua dimensão territorial única "do Minho a Timor", no interior do qual todos eram cidadãos portugueses, quer pela miragem luso-tropicalista da assimilação progressiva das populações africanas aos valores culturais portugueses (não apenas teoricamente mas já de facto) através de um contacto osmótico com uma população branca que se pretendia que emigrasse e se instalasse maciçamente nas colónias. (Borges Coelho, 2015)

Era necessário, portanto, para o angolano indígena ser considerado assimilado saber falar o português. E também saber os modos, a cultura portuguesa, falar corretamente não é só a correção gramatical, mas também a forma de se falar. É preciso participar da cultura portuguesa para ser um cidadão, é preciso ter a mesma correção gramatical e cultura de um português de mesma classe social. Uma tradução, olhando por esse viés, não é uma operação simples. Ela envolve a questão cultural. É um mediador entre dois mundos que não passa só pela linguagem, sendo também uma questão de poder. Uma questão de escolha, pois em uma tradução devemos nos comunicar com o público que irá ler. Parafraseando Benjamin, uma tradução é sempre impossível, mas necessária (Benjamin, 2001).

Aqui dou um depoimento pessoal sobre o bilinguismo, sou tradutora por formação, intérprete de conferências, mais especificamente. Durante um evento, 
dentro de uma cabine, a questão da comunicação impera, e a fala e o discurso devem ser sempre limpos e claros, sempre procurando uma linguagem desprovida de duplos sentidos, buscando a compreensão do texto por parte do ouvinte. Ao intérprete portanto não é permitida a confusão, o bilinguismo na fala.

$\mathrm{O}$ escritor, no entanto, pode se permitir o bilinguismo, pode se permitir a dificuldade de compreensão, porque um texto literário pode sempre estar carregado de múltiplos sentidos. O bilinguismo aqui então não é um problema, mas uma ferramenta. José Luandino Vieira, em suas obras Luuanda (1963), O Livro dos Rios (2006) e O livro dos Guerrilheiros (2009), usa o bilinguismo como ferramenta de construção de um falar outro. Não uma outra língua, mas uma apropriação e uma utilização de duas das línguas existentes na colônia, para, com isso, criar a sua literatura como obra de arte e simultaneamente como posicionamento político. Como afirmou José Luís Pires Laranjeira: “É que vivem do regionalismo, afirmam o combate no terreno da pátria a construir-se, tornam-se concretos, o texto bi-trilinguiza-se, e lê-se facilmente a sua provocação mais imediata: dificultar a leitura dos não-africanos." ${ }^{3} \mathrm{E}$ assim, o bilinguismo de Luandino se mostra como o oposto do trabalho do intérprete, tudo o que deve ser evitado por uma tradução, ele na verdade exacerba o uso dos duplos sentidos, das confusões, da dificuldade.

Em Luuanda, ao longo de três novelas, Luandino apresenta o seu universo linguístico e de personagens. Nessas pequenas novelas, nos mostra os musseques de Luanda. As desigualdades da nação, a relação com a metrópole e a condição subalterna do povo angolano estão presentes em suas páginas, como no cenário onde as histórias ocorrem. É proposital a escolha dos musseques, periferias por excelência de um país já periférico para contar, para fazer parte de sua história. Esse uso da linguagem como tentativa de construção de uma nova língua pode ser visto em diversos momentos, a esse instrumento se soma a denúncia do estado de subalternidade, a partir de histórias que falam do dia a dia dos habitantes da região mais pobre de Luanda, oprimidos pela falta de oportunidades e pela polícia dos tugas.

Ao contar a história de um rapaz que não consegue emprego por sua origem, por ser negro e habitante da periferia e seu conflito com sua avó, com quem mora,

3 PIRES LARANJEIRA, José Luís. Originalidade da Literatura Africana. In: Cadernos de Literatura, n. 3, Centro de Literatura Portuguesa da Universidade de Coimbra/INIC, out. 1979. 
que custa a acreditar no próprio neto, preferindo achar que ele é preguiçoso do que perceber a realidade em que está vivendo, ou mesmo da fome que sentem; a de um cambuta - deficiente físico que manca de uma perna - que vai preso por uma confusão com seus colegas, durante um roubo comum, no qual somente ele é pego e preso, pela denúncia de um dos colegas, motivada por ciúmes; e a de uma briga por uma galinha, com a participação de todo o quarteirão, inclusive dos policiais locais, que ao tentar pegar o ovo, são hostilizados pela vizinhança, mas representam o poder instituído.

Luandino mostra as dificuldades cotidianas em um espaço oficialmente português, mas que não é Portugal nem de fato nem no imaginário. $\mathrm{O}$ domínio colonial deixa marcas na constituição de um país. A começar pelos anos em que sua população era dividida, como vimos, entre cidadãos e indígenas, em que nem todo nascido no mesmo solo tinha o mesmo direito, ainda que levando em consideração que o estatuto não era cumprido na íntegra. Luandino em seu livro nos mostra uma interpretação marxista da questão, coloca a luta de classes como necessária, ao explicitar a condição de subalterno dos indígenas, que não chegam a ser cidadãos. Por essa interpretação, ao conseguir a tomada do poder, a classe oprimida, que então seria dominante, poderia criar uma mudança na sociedade. Essa mudança permitiria a sociedade sem classes, em que todos seriam iguais, sem colonizadores e colonizados. Luиanda nos mostra, de forma diferente em cada história, como essa sociedade de classes interfere na vida de seus personagens, na realidade dos musseques. Como a exclusão, à qual são submetidos por não serem cidadãos completos, cria a necessidade de comunidade entre os angolanos também, um sentimento de comum e de pertencimento que não é relacionado à Portugal Apesar de ainda ser difuso, o sentimento pode ser percebido no pensamento de Lomelino, personagem da segunda história, ao denunciar o seu amigo cambuta como participante do roubo:

As palavras saíam devagar, cheias de tristeza, também custava confessar, mesmo quando é amigo que está ouvir e da profissão ainda, percebe todos os casos, doís dizer tinha falado o Garrido Kam'tuta lá na justiça, que sim, o rapaz ajudara-lhe no serviço, ficou de polícia para avisar as patrulhas se viessem e tudo era uma grande mentira porque até nem tinha aceitado o mulato nesses casos por causa era aleijado e não podia nem saltar quintal nem fugir se ia passar berrida. Mas mais pior era que os polícias nem tinham perguntado nada, não sabiam nada, sentiu bem naquela hora estava ser bufo, ninguém lhe queixara, só o azar que dera-lhe encontro nessa noite e a patrulha desconfiou um saco tão grande. (Vieira, 2006, p.57) 
Foi contando essas histórias simples e dos angolanos que Luuanda ganhou o Grande Prêmio da Novelística no ano de seu lançamento, 1964, confirmando assim, até mesmo para o escritor, então prisioneiro no Campo do Tarrafal, a importância dessa clivagem da língua, dessa diferenciação por meio da arte, entre as duas nações. A indicação para o prêmio causou o fechamento da Sociedade Portuguesa dos Escritores, que lhe concedeu o prêmio já que era claramente anticolonial. Em Luuanda, sua utopia é Angola, não um estado dependente e colônia de Portugal, mas um estado angolano soberano. De formação marxista, Luandino usa a denúncia da opressão como uma forma de indicar o caminho. A solidariedade, como descrita acima, a possibilidade de criação da comunidade, de estabelecimento de um grupo dentro do grupo oprimido para se tomar o poder e a partir daí instaurar mudanças. Já era evidente mesmo em Portugal, a independência das colônias representadas aqui por Angola. A independência das colônias, aqui representadas por Angola, já era evidente mesmo em Portugal. O grupo da Sociedade Portuguesa dos Escritores, presidido por Jacinto Prado Coelho, ensaísta e crítico literário e composto entre outros pelos escritores Alexandre Pinheiro Torres, Manuel da Fonseca e Augusto Abelaira, viu na premiação uma possibilidade de marcar posição contra Salazar, e arcaram com as consequências.

Quarenta anos depois, num recolhimento de mais de vinte anos sem publicar, exceto por um pequeno interlúdio com Kapapa, "pássaros e peixes"4 novela escrita no escopo da coleção lançada para a Expo 98, 98 Mares, José Luandino Vieira regressa ao mundo literário com a publicação de $O$ Livro dos Rios primeira parte de uma trilogia chamada De Rios Velhos e Guerrilheiros ${ }^{5}$. Nele, o escritor parece reforçar o que já dizia em entrevistas a respeito especificamente da língua portuguesa utilizado em seu livro. "Em sua época, era uma força de resistência, tinha uma conotação política. Hoje, acho que se transformou em peça de arte" (Entrevista ao Jornal Estado de São Paulo, 15 nov. 2010). ${ }^{6}$

\footnotetext{
${ }^{4}$ VIEIRA, José Luandino. Kapapa, "pássaros e peixes" Parque Expo 98, Lisboa, 1998.

${ }^{5}$ VIEIRA, José Luandino. De Rios Velhos e Guerrilheiros, Editorial Caminho,Lisboa.

${ }^{6}$ VIEIRA, José Luandino. A força política da linguagem, Entrevista a Ubiratan Brasil para o jornal

O Estado de São Paulo, 15 de novembro de 2010. Disponível em: <http://cultura.estadao.com.br/noticias/geral,a-forca-politica-da-linguagem-imp-,639999> Acesso em 12 fev. 2015.
} 
O trabalho com a linguagem, neste romance, é mais aprofundado do que em qualquer outro livro seu, e se pode falar de uma arte da palavra, de uma poesia em prosa. Aqui o texto de Luandino não se prende a uma denúncia dos fatos, a uma interpretação marxista da realidade atual de Angola, mas se afasta desse registro, não realizando aqui uma representação da realidade e do presente. No romance, a história sai dos musseques, sai do meio urbano ao qual Luandino dedicou o resto de sua literatura e passa para os rios de Angola, como já era anunciado em Kapapa, de onde nos vem seu personagem principal, Kene Vua, o Kapapa, aquele que pesca a arraia, o que anda pelos rios, o sem-azar, o que muda de nome entre o primeiro e o último parágrafo ao longo dos três livros:

Kapapa, meu nome de agora e sempre - eu, e meus peixes. Isto era: ele. Porque chegou a hora de emboscar aquele medo da manhã de fevereiro que eu tinha de ir quebrar as algemas de meu remo, procurar sereia ou peixe-mulher, fugir na mata. $[\ldots]$

Peregrino de meu novo nome, ganhei direito de recusa: fiz o que tinha de ser feito, sempre não quis nada para mim - eu, o Águas do Mar... (Vieira, 1998)

Ao contar a história de Kene Vua - que depois muda de nome, ao precisar, por causa de uma traição à guerrilha, matar o traidor -, ele conta também a história da guerrilha que libertou Angola. Um outro modo de ver a construção da nação. Enquanto em Luuanda a utopia, ainda não alcançada, era o futuro independente e o subtexto aqui aponta para um futuro de luta e construção, que não se resume à independência, mas também se interessa pelo que será feito depois dela, em $O$ Livro dos Rios nos deparamos com o relato de um passado, de uma história que já houve, e com o resgate dessa possibilidade utópica, quer dizer, Angola, a utopia de Angola, não se concretizou, mas ainda existe, ainda pode ser realizada, contando a história passada de Angola, pelos olhos dos guerrilheiros, ele resgata esse sonho inicial de inspiração marxista, sonho de um espaço em que a luta de classes não seja mais necessária. Usando o personagem Kene Vua como uma espécie de "alter ego" para contar uma parte de como foi e porque existiu a guerrilha em Angola, usando esse mecanismo um pouco como é descrito por Margarida Calafate Ribeiro: 
O gesto chave da ligação deste "alter ego" de José Luandino Vieira está na sua escrita, esclarecida pelo próprio autor numa conferência proferida pelo escritor no âmbito de um curso de Literatura Angolana que teve lugar no Centro de Estudos Sociais da Universidade de Coimbra. Na sua intervenção, posteriormente publicada no livro Lendo Angola, Luandino Vieira aproxima um texto de guerra de António Oliveira Cadornega, onde o autor identifica os angolanos em luta, e um texto celebratório da batalha de Quifangondo, nos anos 80 e proferido pelo "General António dos Santos França, a quem eu continuo a chamar por respeito o nosso Comandante "Ndalu", comandante da guerrilha" (Vieira, in Padilha, Ribeiro, 2008: 36). Trezentos e dez anos separam estes dois textos. Mas Ndalu podia ser Cadornega, e Cadornega Ndalu. O que está em causa em ambos os textos - os povos de Angola lutando contra ocupações e portanto pela sua terra em liberdade.

Aqui está uma génese possível do Livro dos Rios - de Rios Velhos e Guerrilheiros e de $O$ Livro dos Guerrilheiros, o segundo livro na ficção angolana, depois de Mayombe de Pepetela, que aborda a questão da luta de libertação e dos seus heróis guerrilheiros, não enquanto acção, fragmentação e ruído dessa luta como em Pepetela, mas enquanto silêncio e memória da luta. (Ribeiro, 2012, p. 95)

$\mathrm{O}$ autor apesar de apoiar o movimento, nunca participou das lutas em campo Foi preso antes da guerra colonial, em 1959. Voltou a ser preso, e condenado a 14 anos de prisão, por "atividades subversivas contra a segurança externa do Estado", em 1961. Em 1964 foram transferidos para o Tarrafal, de onde Luandino saiu em liberdade condicional em 1972 (Vieira, 2009). O personagem Kene Vua fala de um percurso de memória da época em que se buscava a construção do país, em que se buscava a independência do país, fala do que se pensava enquanto se engajavam nessa luta. Esse personagem fala de um percurso de memória da época em que se buscava a construção do país, em que se buscava a independência do país.

Em $O$ Livro dos Guerrilheiros, a história da guerrilha continua a ser contada, dessa vez por uma multiplicidade de vozes: os guerrilheiros Celestino Sebastião (Kakinda) de Tenda Rialozo; Eme Makongo, Mau Pássaro, o Mau-dosMaus; Kibiaka, a quem chamava o Parabelo; Zapata, melhor dizendo, Ferrujado e Kadisu; e, por fim, Kizuua Kiezabu, nosso general Kimbalanganza, nos oferecendo assim não só o ponto de vista do narrador, novamente Kene Vua, mas diversas histórias com uma visão mais ampla da guerra e dos seus resultados. E é aí que se chama a atenção para a manutenção da utopia. Com uma crítica ao general Kimbalanganza, Luandino, por meio de Kene Vua, seu alter ego, deixa claro que a utopia ainda vive, não se realizou, e que ainda há pelo que lutar.

O escritor, recluso desde o fracasso da eleição de 1992, com o reinício da guerra civil, parecia inclinado a uma vida dedicada à agricultura, voltando para o 
interior de Portugal, para o Minho, terra de seus pais, e tratando da lida da terra, fechado para o mundo dos homens quase que totalmente, voltado para as plantas. Mas, em $O$ Livro dos Rios, parece resgatar essa possibilidade de futuro ao nos contar uma guerrilha por dentro, enquanto ela acontecia, ao longo dos rios que cortam Angola. Começando pelo título, que carrega em si muito do que segue, o livro conta a história dos guerrilheiros que andam pelos rios, nas suas margens, mas os rios são também os personagens, uma sobreposição de ideias de margens, de homens e de rios. A guerrilha em si é uma margem que existe à parte da sociedade e, como vemos no livro, quando um dos seus é julgado, tem suas leis e sua ordem. E essa ordem, que é não só da guerrilha, mas do mundo dos rios, parece ser criada por Luandino Vieira para nos afastar da nossa desordem diária. Como se criasse com isso uma reclusão que seria necessária para nos afastar de um mundo de excessos, para podermos compreender os rios, a forma, a linguagem e a ética em seu tempo. Aqui sua intervenção política ocorre no sentido de nos chamar para dentro de nós, de nos colocar em posição de reflexão, de pensamento crítico, e não mais apenas de reação aos muitos estímulos externos, dos quais por vezes nos sentimos dependentes.

Com O Livro dos Guerrilheiros, Luandino nos mostra a continuidade, o hoje, como que fazendo a sua versão da história de Angola, nos chamando para o seu tempo, um tempo da literatura, um espaço também de reflexão, onde o ritmo pode ser reduzido, onde podemos nos envolver pela palavra, confundindo a noção de tempo e de real. Coloca para nós que a utopia ainda está aí e é possível, onde o sonho de uma nação mais justa, onde o capitão não explore o soldado, ainda pode ser desejado e alcançado. E que o seu meio de nos chamar para ela é a literatura.

Três livros que mostram dois momentos de um autor pontuam o começo e a continuação de uma política e de uma luta. Eles mostram a língua como demarcação de realidade e de utopia de nação. E por isso os selecionei para a partir deles escrever sobre como Luandino Vieira trabalha a linguagem de modo a se posicionar politicamente.

No primeiro capítulo desta dissertação, discuto seu investimento na linguagem, e como isso é radical - no sentido de estar na raiz - de sua literatura e projeto de mundo. No segundo, falo mais amplamente como o rio - que flui e que segue, que some e volta a existir - é tema existente em Guimarães Rosa e Luandino, que seguem uma genealogia de criadores com a língua, mas que têm 
mais em comum do que ela. No terceiro, aprofundo-me nas questões políticas levantadas por seus textos e nas suas intenções.

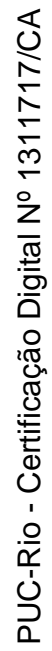




\title{
2
}

\section{A língua como intraduzível}

Luandino, a partir do trabalho que começa com Luuanda e se aprofunda na trilogia De Rios Velhos e Guerrilheiros, da qual até hoje só foram publicados $O$ Livro dos Rios e $O$ Livro dos Guerrilheiros, se utiliza da oralidade e da mistura de construções do português com construções do quimbundo para criar uma variante própria do português, que necessita de mediação para ser compreendida. É como se para poder ser compreendido por um português, fosse necessária uma tradução de seu texto.

Luandino, José Luandino Vieira, angolano, nascido José Vieira Mateus da Graça em Portugal, se mudou ainda criança para Angola e fez parte do Movimento Popular de Libertação de Angola, movimento político e militar que lutou pela libertação de Angola, país que adotou como seu até no nome, Luandino, homenagem a Luanda, sua capital. E ele luta pela sua independência com as armas que possui. Na guerrilha e na literatura, com sua escrita autoral que coloca a todo o tempo a questão da formação de Angola enquanto nação independente.

Parte dessa escrita é a própria maneira como ele utiliza a língua portuguesa, fazendo uso de formas encontradas na língua falda pelos musseques de Luanda. Essa utilização da variante oral também é afirmação de nação e da identidade cultural de Angola. E é uma narração da vida marginal de Angola Como ele afirma na entrevista a Michel Laban ${ }^{7}$ da sua percepção sobre a linguagem como parte da construção da narrativa ao ler Grande Sertão: Veredas:

\begin{abstract}
Eu estava a passar para um caderno escolar a versão final da 'Estória do papagaio' [um dos três longos contos de Luuanda]. E, na visita desse dia, a família trouxe-me este livro, que não era uma oferta porque o dono do livro dizia: 'Eu só tenho este exemplar, mas é pra você ler'. Era o Sagarana de João Guimarães Rosa, que eu li uns meses mais tarde. E então aquilo foi para mim uma revelação. Eu já sentia que era necessário aproveitar literariamente o instrumento falado dos personagens, que eram aqueles que eu conhecia, que reflectiam - no meu ponto de vista - os verdadeiros personagens a pôr na literatura angolana. Eu só não tinha encontrado ainda era o caminho. Eu sabia qual não era o caminho (...), que o registro
\end{abstract}

${ }^{7}$ LABAN, Michel et al. Luandino: José Luandino Vieira e sua obra. Lisboa: Edições 70, 1980. 
naturalista de uma linguagem era um processo, mas que não valia a pena esse processo porque, com certeza que um gravador fazia melhor que eu. Eu só não tinha percebido ainda, e foi isso que João Guimarães Rosa me ensinou, é que um escritor tem a liberdade de criar uma linguagem que não seja a que seus personagens utilizam: um homólogo dessas personagens, dessa linguagem deles. Quero dizer: o que eu tinha que aprender do povo eram os mesmos processos com que ele constrói a sua linguagem, e que - se eu fosse capaz, creio que não fui capaz -, mas se fosse capaz de, utilizando os mesmos processos conscientes ou inconscientes de que o povo se serve para utilizar a língua portuguesa, quando as suas estruturas linguísticas são, por exemplo, quimbundas, que o resultado literário seria perceptível porque não me interessavam só as deformações fonéticas, interessava-me a estrutura da própria frase, a estrutura do próprio discurso, a lógica interna desse discurso.

$[\ldots]$

Depois, portanto li Grande sertão: veredas, e mais se confirmou aquela ideia, aquele ensinamento que me tinha dado quando li Sagarana: a liberdade para a construção do próprio instrumento linguístico que a realidade esteja a exigir, que seja necessário. E sobretudo a ideia de que este instrumento linguístico não pode ser o registo naturalista de qualquer coisa que exista, mas que tem que ser no plano da criação. Portanto, que o escritor pode, tem a liberdade, tem o direito de criar inclusivamente a ferramenta com que vai fazer a obra que quer fazer... Portanto, ensinou-me um sentido, que considero mais completo, da criação. (Laban, 1980. p. 27-28, 35).

Com essa leitura de Guimarães Rosa, feita quando estava preso no Tarrafal, campo de concentração para onde eram mandados os então chamados, pelo governo português, de “inimigos da pátria”, Luandino se dá conta da potencialidade que o uso da língua tem como instrumento de criação de universo ${ }^{8}$.

O que levava consigo para o Tarrafal? A roupa e os livros que estávamos autorizados a ter em Luanda [nas prisões de onde vinham]. Eu estava a estudar italiano e quimbundo, trazia uma gramática de quimbundo, a do [José Luís] Quintão, e trazia um livro de texto e uma gramática de italiano. (Vieira, 2009)

Não a língua exatamente como é falada, que permitiria uma demarcação de hierarquia, entre o que domina a norma culta e o outro, colocaria em questão de outra forma as desigualdades, mas a criação de um universo totalmente outro, que passa pela criação da língua falada nesse universo. Como diz Rita Chaves sobre a escrita de Luandino, em entrevista dada para a União dos Escritores Angolanos: "Não se trata simplesmente de registrar as subversões impostas à língua oficial,

${ }^{8}$ VIEIRA, José Luandino. Entrevista concedida à Alexandra Lucas Coelho, no jornal Público em 15 de maio de 2009. Disponível em: <http://www.publico.pt/politica/noticia/os-anos-de-cadeiaforam-muito-bons-para-mim-1377921> Acesso em 15 mar. 2015. 
mas de aproveitar as potencialidades que os muitos usos facultam, transformandoa numa língua nova" (Chaves, 2015).

\section{1. \\ Subversão e literatura menor}

A desterritorialização - conceito de Deleuze, apresentado em Por uma Literatura Menor - operado por Luandino com o português em seus textos, começando com Luuanda, coloca o uso da língua em seus escritos na esfera do político.

E esse caráter político é dado, assim, porque a maioria hegemônica percebe no texto não a sua língua, mas a língua da minoria, que ali cria o seu espaço. $\mathrm{O}$ que interessa aqui não é apenas o que se fala, mas também a posição de quem fala. Como já mencionado anteriormente nessa dissertação, o autor não escreve na condição de português branco, como poderia, mas escolhe escrever como angolano.

Esse posicionamento político do autor se expressa na linguagem em seus livros e ele usa a, após ler Guimarães Rosa, e escrever Luuanda, como espaço de delimitação da cultura. Assim deixa clara a ideia da língua portuguesa como algo imposto e a noção da língua falada como algo subversivo e não desejado pela metrópole. A prova de que a língua é parte do domínio cultural e político é a constituição de 1933, que enuncia que os direitos políticos nas colônias são ligados ao fato de se falar e escrever português. Se o estatuto do indigenato, como já colocado aqui anteriormente, permite que o "indígena" se torne cidadão ao falar “corretamente" o português. É também lei o domínio sobre as colônias e a ideia de civilizar as populações. Cito a constituição do Estado Novo em Portugal, estabelecendo a pátria portuguesa: 


\title{
CONSTITUIÇÃO DE 11 DE ABRIL DE 1933 \\ ACTO COLONIAL
}

\section{TÍTULO I}

\section{DAS GARANTIAS GERAIS}

\section{ARTIGO 1.}

A Constituição Política da República, em todas as disposições que por sua natureza se não refiram exclusivamente à metrópole, é aplicável às colónias com os preceitos dos artigos seguintes.

\begin{abstract}
ARTIGO 2."
É da essência orgânica da Nação Portuguesa desempenhar a função histórica de possuir e colonizar domínios ultramarinos e de civilizar as populações que neles se compreendam, exercendo também a influência moral que lhe é adstrita pelo Padroado do Oriente.
\end{abstract}

\section{ARTIGO 3."}

Os domínios ultramarinos de Portugal denominam-se colónias e constituem o Império Colonial Português.

$\S 2^{\circ}$ - Os estrangeiros com residência habitual na colónia, por tempo não inferior a cinco anos, sabendo ler e escrever português, podem fazer parte das câmaras ou comissões municipais e juntas locais, até ao máximo de um terço dos seus membros. (Constituição Portuguesa, 1933)

Luandino reconhece, identifica como arma de dominação e critica essa obrigação de se aprender o português. Ele descreve em diversas passagens de Kapapa, O livro dos Rios e O livro dos Guerrilheiros o aprendizado do português como parte da assimilação, da possibilidade de pertencimento a uma sociedade que lhes era refratária. Em O Livro dos Guerrilheiros há uma passagem em que um dos guerrilheiros, ainda menino, fala sobre um dia comum em sala de aula:

Que chovia sobre as matas. Disse então a professora Zeza Barros, contando pelos dedos:

Polegar: que a nossa língua não prestava, soava mal;

Indicador: que a nossa língua não adiantava, era de matumbos;

Médio: que só tinha as palavras podres, asneiras malcriadas;

Anelar: que não pode-se dizer lanche, recreio, aula...

E aí, saliente, saltei eu de mindinho levantado no cu do ar:

- Pode-se dizer professor: mesene!

- Isso é professor de protestante, judas! - ela gritou.

E o Felito, com riso dos outros todos, bombiadores da sua bicicleta, riu:

- É língua de cão. Nem pode-se dizer bicicleta!

Que tínhamos de dizer xikeleta, xika, bina, biscla. (Vieira, 2010, p. 274) 
Nesse trecho, podemos ver que Luandino enxerga a língua como instrumento de poder e de dominação. A professora coloca o menino em seu devido lugar, de subalterno, de utilizador da língua "errada", afinal, é como se ela não servisse nem para falar as coisas boas, seria como uma língua de coisas pequenas e caseiras, que não tem os termos que permitem falar da vida civilizada, por exemplo, da escola. Isso, portanto, perpassa e é um dos objetivos da obra de Luandino: denunciar a percepção da língua falada nas ruas de Angola como subalterna e a sistemática inculcação oficial (a Professora) de que a língua tradicional é vulgar e o português europeu uma Língua maiúscula. Explicita assim sua forma de trabalhar, colocando a linguagem como parte da construção de significado do enunciado. Aqui não estamos discutindo somente o que se diz, mas como se diz e quem diz. Quem enuncia e como enuncia modificam o valor do que é enunciado.

A linguagem da forma como ele usa tem o peso, portanto, de se diferenciar do português da metrópole, de marcar uma "angolanidade" da fala e da escrita, de delimitar culturalmente um espaço que não é mais o do colonizador nem do colonizado, mas de um angolano, que busca ser livre, que luta por isso, por sua independência e autonomia, uma luta que começa em Luanda, mas que é uma constante e não termina na independência. Mesmo em seus dois últimos livros, já escritos após o fim da guerra de libertação e que têm um tom memorialista, Luandino mantém a língua nesse espaço privilegiado de criação de comunidade. A língua, nos livros de Luandino é colocada como um instrumento de construção cultural do país é ela que permite a comunidade de Angola. Uma nação existe a partir do momento em que a "comunidade imaginada" de seus habitantes existe, e uma das identidades dessa comunidade imaginada é a língua e a narrativa, a história que a funda. A ideia de que pertencem todos à mesma comunidade, ao mesmo espaço. Cito aqui Anderson:

\footnotetext{
A ideia de um organismo sociológico atravessando cronologicamente um tempo vazio é uma analogia exata da ideia de nação, que também é concebida como uma comunidade sólida percorrendo seja em sentido ascendente ou descendente. Um americano nunca vai conhecer, e nem sequer saber o nome, da imensa maioria dos seus 240 milhões de compatriotas. Ele não tem ideia do que estão fazendo a cada momento. Mas tem plena confiança na atividade constante, anônima e simultânea deles. (Anderson, 2008, p. 56)
} 
A comunidade é imaginada, não conhecemos cada um de seus membros, mas temos em comum o tempo, vivemos nessa simultaneidade. $\mathrm{O}$ idioma português tem o papel de ser parte do que forma a ideia de "Império Português". É a língua de poder e de administração, de criação dessa comunidade. Ele é necessário para que se tenha o status e os direitos de um cidadão. A língua portuguesa é a pátria, na famosa frase de Fernando Pessoa, aqui analisada por Eduardo Lourenço:

Há vários anos, uma frase de Pessoa a respeito de sua relação individual com a língua em que se tornou célebre tornou-se citação obrigatória. Por sua vez, a mesma citação converteu-se numa litania repetida através do espaço da língua portuguesa, ao mesmo tempo como prova da assimilação de "língua" e "pátria" e como sacralização desse laço indissolúvel. Toda gente conhece a frase de Pessoa: "A minha pátria é a língua portuguesa". Claro está que o autor do Livro do desassossego em geral tão irônico, não teria sido tão peremptório se o seu intento tivesse sido apenas o de sublinhar a veneração que merecia a seus olhos aquela língua - ademais língua "meio" escolhida - em que escrevia os seus poemas e sonhava o mundo. Na verdade, o que Pessoa queria dizer foi que, à parte a língua portuguesa, universo por assim dizer imaterial do qual extraía a matéria dos seus sonhos e nele inventava um mundo fora do mundo, ele não tinha pátria. Quer dizer, pátria no mero sentido "patriótico" e, de algum modo, anedótico do termo. (Lourenço, 2001, p. 125)

A pátria para Pessoa era a língua por ser onde ele habitava. Do mesmo modo, para Luandino, é a construção de seu mundo que importa, da sua pátria, da sua comunidade, em torno de sua língua, que não deixa de ser o português, mas não é o mesmo português que o ensinado pela metrópole, é uma língua híbrida, com palavras e construções do quimbundo, principalmente, que marca a sua diferença de Portugal, uma língua nova. A noção da língua como parte da nação é ainda descrita por Lourenço:

A pátria, com o significado de "nação", é de invenção recente, tal como o termo nação para designar uma "comunidade de cidadãos e não de meros súditos". Outrora a nação designava, naturalmente, o lugar em que se nascera e era seguida de um adjetivo que se referia à língua que aí se falava. Em Paris, no fim de Idade Média ou nos tempos do Renascimento, os estudantes agrupavam-se por nações: a nação portuguesa, a escocesa etc. Entre nós, a noção de nação designava, sem adjetivos, o povo judaico, "gentes de nação". Na realidade, na Europa medieval, que é ainda a de uma cristandade não dilacerada, a relação "língua-pátria", ou "língua-nação", não tem qualquer ressonância particular. É um dado de fato, uma maneira de distinguir os povos que têm uma fala diferente e que, aliás, comunicam pouco entre eles. A língua não é ainda um sinal de eleição particular, de singular atenção enquanto fator de uma qualquer exaltação anacronicamente nacionalista. 
Como é sabido, a língua do culto e dos cultos, a língua nobre, é, e será durante muito tempo, o latim." (Lourenço, 2001, p. 127-128)

A língua só em tempos modernos se torna uma demarcadora de comunidades. A partir do fim do domínio da igreja e da clivagem entre cosmologia e história, quando o latim deixa de ser a língua dos cultos e passa a ser mais uma língua, e quando a literatura e os jornais passam a exercer o papel da criação da comunidade. Luandino usa essa premissa, a da criação de comunidade na literatura e na língua, sabendo que a nação existe através de sua narração. Essa narração e essa língua existem enquanto demarcam esse território, reterritorializando a língua, Luandino cria um mundo. Como escreve Anita Martins de Moraes:

O trabalho com a língua não se restringiria a uma tentativa de retratar o falar popular, numa chave naturalista, mas seria uma recriação. Trata-se de um aprendizado que marcaria sua obra: não era preciso se restringir ao português do português (o colonizador, afinal), tampouco restringir o português popular ao nível do documental (que, em termos de realização literária, costuma resultar no duplo registro: o português padrão, tido como correto, na fala do narrador, e, na fala de certas personagens, o português "regional", para não dizer incorreto, produzindo-se uma hierarquia, a afirmação de uma norma e um desvio). É a possibilidade de inventar - aproveitando as possibilidades internas da língua e também aproveitando o confronto de variantes linguísticas ou mesmo de línguas (como no caso do escritor angolano, as línguas africanas, especialmente o kimbundo, e o português) , é a possibilidade de inventar uma linguagem própria para expressar a sua realidade que Luandino diz ter aprendido com Rosa. (Moraes, 2012)

Como tentei mostrar, apesar do português ser a língua do colonizador obrigatória para a cidadania, não foi essa a escolha do autor ao escrever sua obra. A variante oral, especificamente dos musseques, permite uma terceira via, que não é nem o português nem o quimbundo. E que afirma a nação Angola também como híbrida. 


\title{
2.2. \\ O espaço da tradução
}

Luandino em seus livros não simplifica o trabalho de um tradutor. Agindo, ele mesmo, como um intermediário entre a linguagem oral das periferias de Luanda, que ele retrata em Luuanda, ou apenas do português oral da Angola que ele habita, Angola que para ele já é separada de Portugal, ele nos entrega uma língua em seus livros que precisa de uma mediação, mesmo que não seja uma mediação de uma tradução tradicional. Uma tradução literal de sua obra para o inglês, por exemplo, a tornaria próxima do incompreensível para um anglófono. Mas afirmo aqui que essa dificuldade é parte da intenção de Luandino Vieira em seus livros, que não queria que fossem facilmente lidos pelos portugueses. A dificuldade de leitura é um objetivo da escrita aqui, para afastar o leitor desinteressado e chamar o interessado para entrar no mundo de suas histórias, mergulhar e procurar entender. O objetivo aqui é um afastamento do resto do mundo para a leitura, é uma inscrição da leitura como um ato político, de insubordinação ao Portugal colonial, que vive com um só governo, sem fronteiras. É um ato político Isso pode ser visto nesse pequeno trecho que descreve a passagem para a república portuguesa, em 1910 e as novas relações de Angola com Portugal pelos olhos do personagem, ainda criança.

\begin{abstract}
Em éditos e brado, faziam saber que já não havia que pagar impostos a el-rei de Portugal, que nada mandava. $\mathrm{O}$ novo imposto era de continência-à-bandeira, para todos, velhos e novos, ainda que não foram baptizados ou de pé calçado. Ou descalço. E queriam fechar todas as crianças em escolas até aprenderem a ler e escrever a língua da república. E sendo ainda pouco ancião se levantou de novo o mesmo Quiçongo, o Terrível, com seus portugueses verdadeiros debaixo da bandeira azul de el-rei de Portugal; batucaram tambores por luas e léguas; de súbito ardiam os postos com sua nova bandeira verdirubra. (Vieira, 2006, p. 841)
\end{abstract}

Com a república proclamada, percebe o personagem, a mudança: os impostos e o português eram para todos. Começa aí uma nova etapa da relação entre a colônia e a metrópole, Luandino Vieira, ao escrever dessa forma, busca criar livros que atingiriam essa intraduzibilidade, uma incapacidade de compreensão por falantes do português não nascidos em Angola, portanto não familiarizados com as questões culturais do país, e aí falo não somente do 
vocabulário, mas da forma como o raciocínio é colocado e das questões ligadas a costumes e hábitos.

Uma língua difere da outra também pelos recursos que oferece para narrar os acontecimentos. Por exemplo, em francês, não há diferenças entre o que em português são os verbos "ser" e "estar", uma vez que o verbo para definir as duas situações "être" é o mesmo, portanto a permanência ou a transitoriedade das coisas é indiferente na hora de se contar o que acontece. Se a história das centenas de palavras para branco não é verdadeira, a construção da língua também é cultural e é uma via de mão dupla, interferindo na sua própria construção. Com seu trabalho com a linguagem, Luandino explicita essas diferenças culturais em seu texto, fazendo com que ele não seja de fácil compreensão para quem não possui os códigos culturais necessários, para quem não saiba se, em Angola, tal coisa se torna mais ou menos importante, ou se a construção frasal por ele empregada é uma regra ou uma exceção. O escritor oferece, com isto, inúmeras camadas de sentido, que passam pela constituição material do texto, como afirma Miriam Rose Brum-de-Paula:

\begin{abstract}
Esse recorte está ligado a uma certa maneira de ver o mundo através da linguagem. Isso reforça a existência de uma relação entre conceitualização linguística, cultura e pensamento e, consequentemente, de uma diversidade das representações construídas através das línguas. (Brum-de-Paula, 2008, p.41)
\end{abstract}

Portanto, as línguas existem enquanto representação de um universo cognitivo existente, não separadas deles, e ao se colocar dentro do universo cognitivo de Angola, e não de Portugal, Luandino separa um território na escrita. Ele coloca um território claramente separado do léxico português, portanto da forma de ver o mundo. O mundo aqui é visto com olhos angolanos, portanto a língua aqui declara uma independência e uma novidade, um mundo diferente e específico, onde coisas específicas têm nome, e uma delas, como diz o trecho citado no subtópico 1.1 , não é bicicleta. 


\section{3. \\ Luandino e seu universo}

Esse universo linguístico é apresentado pela primeira vez em Luuanda, que não é o seu primeiro livro, mas é o primeiro em que, influenciado pela leitura de Guimarães Rosa, Luandino se permite a criação dessa linguagem, usando termos do português e do quimbundo e construções do português falado em Angola. Ao longo de três pequenas novelas, nos mostra os musseques de Luanda, As desigualdades da nação, a relação com a metrópole e a condição subalterna do povo angolano estão presentes em suas páginas. O uso da linguagem como tentativa de construção de uma nova língua angolana é claro em diversos momentos, e a denúncia do estado de subalternidade também, a partir de histórias que falam do dia a dia dos habitantes da região mais pobre de Luanda, oprimidos pela falta de oportunidades e pela polícia dos tugas. O tema das histórias aqui é claramente político, falam de situações de opressão cotidianas sofridas pelos angolanos, sobretudo os menos favorecidos, em um tom de denúncia da opressão por eles sofrida. Isso pode ser visto, entre outros, no trecho da Estória da Galinha e do Ovo em que chegam os policiais:

Só mesmo quando o sargento começou aos socos nas costas é que tudo calou e começaram ainda arranjar os panos, os lenços da cabeça, coçar os sítios das pancadas. Os dois soldados tinham também entrado atrás do chefe deles, sem licença nem nada, e agora, um de cada lado do grupo, mostravam os cassetetes brancos, ameaçando e rindo. Mas o sargento, um homem gordo e baixo, todo suado, tinha tirado o capacete de aço e arreganhava:

- Bando de vacas! Que raio de coisa é esta? Eh!? O que é que sucedeu? (Vieira, 2006, p. 128)

Aqui a polícia, organizada pelo governo português, entra no meio da discussão sobre de quem seria a galinha batendo, antes de perguntar o que acontece. Ela é violenta, opressora, e no trecho seguinte, chega a tentar ficar com a galinha, o objeto da discórdia:

- Vocês estavam a alterar a ordem pública, neste quintal, desordeiras! Estavam reunidas mais de duas pessoas, isso é proibido! E, além do mais, com essa mania de julgarem os vossos casos, tentavam subtrair a justiça aos tribunais competentes! A galinha vai comigo, apreendida, e vocês toca a dispersar! Vamos! Circulem, 
circulem para casa!

Os soldados, ajudando, começaram a girar os cassetetes brancos em cima da cabeça. (Vieira, 2006, p. 129)

A mediação da linguagem em Luuanda é quase transparente, a narrativa é possante. Mas ao mesmo tempo de modo claro e culturalmente identificável, é possível perceber a linguagem como algo à parte do todo que é a narrativa, linear, nas três histórias que se constroem com começo, meio e fim. $\mathrm{O}$ papel da linguagem nem sempre fica claro para qualquer falante do português, Por exemplo, no Brasil, para se compreender o texto, é necessária uma tradução simples de termos e estruturas pouco conhecidas do quimbundo. Mas são pequenas interferências que aparecem ao longo do livro como no trecho abaixo, da segunda novela, em um momento em que o personagem principal se encontra preso, e há uma tentativa de se esclarecer a história que levou a isso, uma espécie de entrada na história de uma fala externa. Algo parecido com a fala de um griot, contador de histórias tradicional africano, que no meio de seus relatos sempre insere sua fala, uma digressão de natureza moral:

\begin{abstract}
Dizia Xico Futa:
$[\ldots]$

É assim como um cajueiro, um pau velho e bom, quando dá sombra e cajus inchados de sumo e os troncos grossos, tortos, recurvados, misturam-se, crescem uns para cima dos outros, nascem-lhes filhotes mais novos, estes fabricam uma teia de aranha em cima dos mais grossos e aí é que as folhas, largas e verdes, ficam depois colocadas, parece que são moscas mexendo-se, presas, o vento é que faz. E os frutos vermelhos e amarelos são bocados de sol pendurados. As pessoas passam lá, não lhe ligam, vêem-lhe ali anos e anos, bebem o fresco da sombra, comem o maduro das frutas, os monandengues roubam as folhas a nascer para ferrar suas linhas de pescar e ninguém pensa: como começou esse pau? Olhem-lhe bem, tirem as folhas todas: o pau vive.

[...]

É assim o fio da vida. Mas as pessoas que lhe vivem não podem ainda fugir sempre para trás, derrubando os cajueiros todos; nem correr sempre muito já na frente, fazendo nascer mais paus de cajus. É preciso dizer um princípio que se escolhe: costuma se começar, para ser mais fácil, na raiz das coisas, na raiz dos casos, das conversas.
\end{abstract}

Assim disse Xico Futa. (Vieira, 1963, p. 58-59)

O trecho acima aparece no meio da narrativa do personagem cambuta, como uma interferência do narrador na história, que é ao mesmo tempo um griot, a nos colocar sua moral, a da necessidade de chegar na raiz das coisas para poder 
entendê-las. O griot pode ser visto também no fim do livro, com a fala "Minha estória. Se é bonita, se é feia, vocês é que sabem. Eu só juro não falei mentira e estes casos passaram nesta nossa terra de Luanda."

Na trilogia De Rios Velhos e Guerrilheiros, iniciada com O Livro dos Rios e continuada com $O$ Livro dos Guerrilheiros, a coisa se passa de forma diferente. Começando por uma questão de ambientação. Pela primeira vez suas histórias não se passam em Luanda, ou nos musseques, mas nas matas onde se passou a guerrilha. O Livro dos Rios não utiliza uma narrativa linear - Kene Vua conta ao mesmo tempo a sua história com o pai singrando pelos rios de Angola, a história dos rios de Angola e a sua história de guerrilheiro, lutando pela utopia de uma Angola livre, de uma Angola em que não haja opressão, em que as pessoas possam ter igualdade de oportunidades. Essa questão, somada ao trabalho de linguagem, que se aprofundou com os anos - e tinha chegado ao seu ápice em Nós, os do Makulusu, escrito em 1967, ainda na prisão do Tarrafal -, faz com que aqui o texto de Luandino precise de uma mediação maior, e essa mediação, apesar de não explícita, de não ser personificada, é a mediação do tempo e do espaço. Precisamos de tempo e de separação para nos tornarmos, nós mesmos, os tradutores do texto de Luandino, precisamos nos recolher e nos concentrar para melhor compreender o texto, para perceber suas nuances e decodificar seu sentido e intenção. Em um trabalho que, ao longo do tempo só se aprofunda, ele nos pede dedicação e tempo. Para que possamos compreender o local de fala. Para que possamos entrar com ele nos rios d'O Livro dos Rios e assim compreender o livro.

O livro começa nos falando desses rios. Do conhecimento que Kene Vua, nosso narrador e personagem principal, tem dos rios. Soa como um convite, repetido diversas vezes. Para entrarmos no rio e navegarmos junto. Para podermos aprender o que o rio tem a nos dar. Para podermos, como um rio, não termos a definição a priori de onde iremos, mesmo ao final, os rios que nos levaram para lá, e aqui cito dois trechos, do início e do final do livro, em que se repete o convite e a afirmação de conhecimento dos rios:

Conheci rios.

Primevos, primitivos rios, entes passados do mundo, lodosas torrentes de desumano sangue nas veias dos homens.

Minha alma escorre funda como a água desses rios.

Só que, na guerra civil da minha vida, eu, negro, dei de pensar: são rios demais - vi 
uns, ouvi outros, em todas mesmas águas me banhei é duas vezes.

[...]

Digo mais: também eu, sou um rio. (Vieira, 2011, p.97)

Conheci rios.

E sonhei um sonho.

Peregrinando os rios deste mundo, fui dar a um sítio onde tinha uma caverna; e me deitei junto com ela para descansar; e logo-logo, adormeci. E no sono onde que fui, adiantei sonhar nosso rio Kwanza desenhado como era uma jiboia de três caudas.

[...]

Aditemos rios, águas de sangue. (Vieira, 2011, p. 576)

O escritor coloca a si e ao leitor como rios também. E recorre a citações, às avessas, declarando que, sim, se banhou duas vezes no mesmo rio, ao contrário do que falava Heráclito. Aqui anuncia que ler o livro não é algo que prescinda de uma espécie de tradução. Aqui percebemos que é um livro que exige nossa atenção, nosso cuidado. Precisamos entrar nesse rio. Para que possamos desdobrar todas as possibilidades por ele oferecidas. Há, por exemplo, uma citação logo no início de Langston Hughes, poeta americano, um dos líderes da Renascença do Harlem, que fica aparentemente deslocada. Apenas, depois da epígrafe, uma página em que se lê: "(a tribute to Langston Hughes)" (Vieira, 2011). Langston Hughes escreveu um poema chamado The Negro Speaks of Rivers, que foi traduzido livremente por Luandino no começo de seu livro. Novamente, o livro se mostra cheio de pequenos momentos de introspecção e tradução. De percepção do que se quer falar e do que precisamos ouvir, de descobertas que exigem trabalho de decodificação.

Em O Livro dos Guerrilheiros, a narrativa é construída enquanto a fala de diversas pessoas, conta a história de diversos guerrilheiros, ela ouve a voz agora não de diversos autores, mas de diversos personagens. Luandino aqui quebra a quarta parede do romance reiteradas vezes nas notas de pé de página e no final do texto. Ele se deixa confundir com o narrador, Kene Vua, em diversos momentos, e confunde a sua história com a que está sendo contada. Ele chega mesmo a declarar que o Kapapa, o Kene Vua, é ele, "E o general Kimbalanganza tinha aprisionado na canoa do Kapapa, no ximbicanço dela pelo quintal do mar alheio. E o general ofereceu de lhe pôr de marinheiro e logístico do convés de seu iate. E o Kapapa (isto é: eu) respondeu:” (Vieira, 2011, p. 892)

O romance assume um tom memorialista, contando sobre a guerrilha de dentro, pela voz dos guerrilheiros. Ele coloca a importância mesmo da linguagem 
na voz dos guerrilheiros, como vimos na citação no início do texto. Em determinado trecho, em uma nota do autor, ele, quebrando a quarta parede, fala sobre como ouviu a conversa:

Quando ouvi, pelo ex-guerrilheiro Kene Nvua - o meu amigo Diamantinho Kinhoka, o Kapapa - esta biografia, apressei-me a ler-lhe, do meu livro Nós, os do Makulusu umas passagens referentes a uma personagem. Chamava-se igualmente Kibiaka. Tinha-me surgido, em sonhos, no Tarrafal de Santiago, Cabo Verde, naquela semana do ano de 1967 em que todas as noites me apareciam os factos ou as palavras que davam origem, no dia seguinte, à escrita. Sentado numa pedra, encostado ao tronco de uma velha acácia, frente à capela-biblioteca do campo de concentração, escrevia sem poder mudar de sítio: só debaixo daquela árvore adquiria o estado meio sonâmbulo que ditou o romance. Contei tudo isto ao Kapapa. Ele me olhou, assanhado, com a minha dúvida e ripostou sem pestanejar: «E qual é, ò branco?!... O quilulo do avô dele t'avisou nos sonhos. Te confiou entanto que escritor...» - e acabou de beber sua cervejinha, sem nunca mais. Sempre achei questão de preguiça mental aceitar coincidência ou intervenção sobrenatural para explicar factos reais. Para tudo tem que ter uma explicação cabal, mesmo que ninguém a saiba. É só questão de paciência e tempo. Paciência, vou tendo; tempo é que a cada dia que passa, fica mais curto. Terei de aceitar a coincidência? (N. do A.) (Vieira, 2006, p. 481)

Aqui Luandino nos coloca na posição de duvidar acerca de quem diz o que diz, de onde vem a história, e como ele sabe disso, talvez porque ela tenha vindo para ele em sonho, se utilizando do papel do narrador omnisciente, mas justificando com a fantasia. Seu livro anterior é como um sonho que levou a esse, e o personagem aparece novamente em outro contexto. Não negando, mas continuando a questão da militância política pela formação do país - questão que de resto já não faz mais parte da necessidade de sua literatura; o país, com ou sem guerras civis, já é uma realidade, há um Estado estabelecido, um governo Angola, não é mais província ultramarina, ou colônia - Luandino discute outra utopia, que precisa de tempo e espaço, a utopia de que cada um possa fazer essa mediação, de que cada um de nós tem em si, do desejo de humanidade e de igualdade e a capacidade de pensamento crítico para realizá-la. É preciso desse tempo para perceber como, apesar de constituído legalmente, ainda é necessária a luta pelo país, porque a construção de um país é um contínuo e é permanente. Mas não é a mesma do começo da obra do escritor, o país já existe, mas ainda não é como foi sonhado, sua realidade está longe da utopia original. Mas essa utopia não é inalcançável e ela existe na soma da vida cotidiana e da vida literária. Não se trata mais de expor o que ninguém mostra, isso já foi feito, até por ele Luandino, mas 
de falar do que se passou, a memória, e a partir disso poder criar o novo de novo.

Há uma tradução das palavras, com um glossário ao final d'O Livro dos Guerrilheiros, pode-se fazer uma comparação com as estruturas do quimbundo e pode ser refeita com liberdades estilísticas, ou ordem de palavras pouco ortodoxa ao se traduzir, por exemplo, para o inglês. Mas esse tempo que o autor nos pede, da ética, da construção de outro raciocínio, é algo além dessa operação de tradução linguística. Aqui não cabe meramente conhecer e ter noção da história ou cultura de Angola. Precisamos nos dispor a participar da leitura do livro, seguir por eles como seguimos pelos rios, como seguimos nossos companheiros.

"O caminho do homem na morte..." - sempre procuro mais essa maravilha em minha vida. "Encontrei meu caminho, meu irmão camarada..." mas me calei, falei eu, começava de dar encontro sem mais as palavras de meu avô para me guiar, meio xalado bíblico, ficava perdido entre fumos de quimbos e camionetas de contrato. (Vieira, 2006, grifos do autor)

Outro momento em que Luandino demonstra o projeto de mudança que pretende é ao final d'O Livro dos Guerrilheiros, quando fala do general Kimbalanganza, um ex-combatente que enriqueceu, subentendidamente à custa da população. A mudança da qual falamos, portanto, é a utopia ainda, é a Angola do futuro almejado, uma Angola menos desigual e mais comunitária, como nas utopias dos anos 60. Kene Vua vai visitar o ex-companheiro e fica indignado com seus iates, com sua exploração do corpo feminino e com sua forma grosseira de referir-se a ele:

- Não tens vergonha de andar numa chata?!...

- Tenho! - disse eu. - mas é pró camarada general andar de iate. Senão, não dava!... O mar não cabia para os dois... (Vieira, 2011)

Se estivermos atentos para esse novo tempo, da leitura crítica, do pensamento a respeito do mundo que lemos e a respeito dos estímulos que dele recebemos, poderemos então ser o rio, poderemos ser tradutores de uma ideia de mundo. O rio nos dá essa possibilidade de corte e de caminho. De seguir o fluxo, de nos perdermos e de nos encontrarmos. Os guerrilheiros seguem pela cartografia estabelecida no primeiro livro. Eles andam pelos rios de Angola da mesma forma. E nós os seguimos. 


\section{3 \\ Os rios que comunicam}

Paternidade. Língua. Unidade. Nação. Tempo. São questões presentes em José Luandino Vieira, em sua trilogia De Rios Velhos e Guerrilheiros. São questões presentes no conto A Terceira Margem do Rio, de João Guimarães Rosa. Ambos, separados pelo tempo, seguem uma genealogia. Luandino declarou diversas vezes, como nas entrevistas para Alexandra Lucas Coelho ${ }^{9}$ em 2009 ou para Michel Laban ${ }^{10}$ em 1977, ter sofrido a influência dos contos de Guimarães Rosa que lhe permite quebrar uso do português padrão até então e passa a escrever usando a sua interpretação da variante oral do português em Angola. Mas o escritor fala pouco sobre a influência de Rosa nos enredos e histórias construídos apesar de deixar algumas indicações.

Repito aqui a citação da introdução, em que, durante uma entrevista, Luandino claramente explica sua percepção da criação da linguagem que constrói em seus livros. A se notar que ele leu Grande Sertão: Veredas ${ }^{11}$ após ter escrito seu livro Luuanda, onde começa a criar sua linguagem, mas já tinha lido Sagarana. Com Grande Sertão, ele confirma a sua ideia do poder político de criação embutido especificamente na linguagem:

Depois, portanto li Grande sertão: veredas, e mais se confirmou aquela ideia, aquele ensinamento que me tinha dado quando li Sagarana: a liberdade para a construção do próprio instrumento linguístico que a realidade esteja a exigir, que seja necessário. E sobretudo a ideia de que este instrumento linguístico não pode ser o registo naturalista de qualquer coisa que exista, mas que tem que ser no plano da criação. Portanto, que o escritor pode, tem a liberdade, tem o direito de criar inclusivamente a ferramenta com que vai fazer a obra que quer fazer... Portanto, ensinou-me um sentido, que considero mais completo, da criação. (Laban, 1980, p. 35)

Isso dito, neste capítulo quero me ater ao tema, não à linguagem. É preciso

\footnotetext{
${ }^{9}$ VIEIRA, José Luandino. Entrevista para Alexandra Lucas Coelho, no jornal Público em 15 de maio de 2009, acessada em 15/03/2015, disponível em http://www.publico.pt/politica/noticia/osanos-de-cadeia-foram-muito-bons-para-mim-1377921.

${ }^{10}$ LABAN, Michel et al. Luandino: José Luandino Vieira e sua obra. Lisboa: Edições 70, 1980

${ }^{11}$ ROSA, João Guimarães. Grande Sertão: Veredas, Editora Nova Fronteira, Rio de Janeiro, 2006.
} 
reiterar isso, pois muito já se falou e discutiu sobre a influência exercida pelos escritos de Guimarães Rosa na escrita de Luandino Vieira. Afinal, o próprio Luandino admite isso em entrevistas. Ao ler os livros de Guimarães Rosa enquanto estava preso no Tarrafal, a prisão política portuguesa, Luandino se abriu para a possibilidade da modificação da língua, do emprego da variante oral do português de Angola como língua escrita em seus livros. E essa colocação da linguagem falada, essa criação de uma língua mista que não era exatamente o português oficial, da metrópole, foi permanente desde então em seus livros. Uma posição política que se mostrava também no tema e no cenário de seus livros, a vida nos musseques, as periferias pobres de Angola, que estavam à margem do poder português.

Após longa pausa, Luandino volta a escrever. E é quando volta, com a trilogia De Rios Velhos e Guerrilheiros, que se afasta do tema urbano, dos musseques, e se volta para o percurso das guerrilhas pelo meio das matas e dos rios de Angola. E é sobre essa questão, esse percurso desenhado por ele nesses dois livros e onde isso o aproxima da prosa de Guimarães Rosa que quero falar. Luandino assume que os dois livros são livros que necessitam de interpretação. Que ele coloca armadilhas de citações e de sentidos ocultos em suas páginas. E nos convida a desvendar esse caminho. Cito Luiz Maria Veiga:

Mas o leitor, diante da afirmação que diz ser O livro dos guerrilheiros um romance, poderia perguntar: se é assim por que encontramos, abaixo do título, na capa e na página de rosto, a indicação "- narrativas -"? É provável que seja porque, mais uma vez, o autor quis jogar com seu público, dando-lhe mais que um texto a ler: propondo enigmas a decifrar e desvendar. Em nota assinada por Andrea S. Sanches e publicada num semanário angolano (Novo Jornal, n. ${ }^{\circ}$ 90, de 9/10/2009, p. 15), com os títulos "Luandino Vieira com novo livro" e "Memórias fictícias de um exguerrilheiro", o próprio autor dá instruções de como se aproximar do texto, diz que o livro "deve ser lido devagar pois exige um grande esforço de interpretação". (Veiga, 2009, p. 282)

Esse "esforço de interpretação" para compreendermos o português escrito, a narrativa, e encontrarmos nas entrelinhas e citações tudo que ele fala. Essa dificuldade é portanto intencional, como uma conquista do texto, como o autor e a luta por sua utopia. 


\title{
3.1. Logótetas
}

Por Luandino ter a capacidade de criação de uma língua escrita diferente da norma culta estabelecida, José Eduardo Agualusa, em seu livro Milagrário Pessoal (2010), o inclui no que chama de uma espécie de academia de logótetas. Apaixonados por novas palavras, criadores de novas palavras. E dessa academia fariam parte também Manoel de Barros e Mia Couto, todos eles inspirados por Rosa. Produtores de neologismos, brincantes com a linguagem, amantes das palavras e das construções possíveis com elas e a partir delas. E isso é realmente uma constante da obra de todos. No romance, os dois personagens principais se deparam com textos repletos de neologismos, que não sabem de onde podem ter surgido. Buscam o criador desses neologismos e chegam durante uma conversa sobre isso na ideia da tal academia:

\begin{abstract}
Um génio?
Não sei, não faço ideia, pode ser um grupo, sorriu, uma espécie de academia de logótetas.

Estou a ver. Soltei uma gargalhada. Gosto de rir alto. É o que me sobra da infância, O que teima em mim de africano. Aos oitenta e tantos anos já só sou preto quando rio. Uma alegre academia de logótetas. Digamos, a Academia Guimarães Rosa. Nem é difícil adivinhar os nomes dos membros: Manoel de Barros, o poeta do Pantanal, segundo o qual os homens precisam de reaprender a errar a língua:

$[\ldots]$

Gostas? Devias ler. Teríamos ainda na tal academia o angolano Luandino Vieira, meu conterrâneo, que sofreu uma epifania ao ler Rosa enquanto estava preso no Tarrafal, ilha de Santiago, Cabo Verde, no início dos anos sessenta, e deixou de ser um militante nacionalista com vagas ambições literárias para se transformar num genuíno escritor. Por fim, Mia Couto, moçambicano da Beira, que chegou a Rosa através de Luandino, e se tornou em pouco tempo no mais conhecido produtor de neologismos da língua portuguesa. Faz uma falta danada nessa academia um escritor português. (Agualusa, 2010, p. 27)
\end{abstract}

Os criadores de mundos com suas palavras. Não falarei aqui de Mia Couto ou de Manoel de Barros aprofundadamente. Mas sobre a ideia de que há uma "academia", para usar as palavras de Agualusa, que os une não só pela sua atividade criativa, mas pelo que a impulsiona. A demonstração de domínio da língua portuguesa pelo sertão, para Rosa, pelo Pantanal, para Manoel de Barros, e pelas antigas colônias, para Luandino e Mia Couto, é importante. Ao mesmo 
tempo que universo deles não é o centro de tudo, o centro dos jornais e do mundo é importante para eles. Não por acaso. Rosa escreveu em uma época em que o Brasil se modernizava, em que Brasília era construída e no entanto, excetuando por um conto, ele não usa a construção do interior do Brasil como seu tema. Seu tema é o sertão, é a margem, são os rios.

E aí os autores que com ele têm a epifania da linguagem, como diz Agualusa, podem ter com ele também a epifania da margem. A percepção de que a história a ser contada não é só a história do centro, que a margem tem uma história sua, importante e diferente da do centro é uma percepção compartilhada com Rosa. De formas diferentes, e com pontos de vista diferentes, é a história que os interessa porque é o nada, é a história do que não é uniforme, do que é contrahegemônico, do que entra no campo das ideias para lutar por seu espaço. Como diz Mia Couto, em Rosa ele aprendeu que:

É importante situar em que contexto histórico João Guimarães Rosa escreve. Grande parte da obra Rosiana é escrita quando os brasileiros fazem nascer do "nada" uma capital no interior desse sertão (Brasília acabava de ser construída). O que estava ocorrendo era a consumação do controlo centralizado de uma realidade múltipla e fugidia.

Na realidade, o sertão de Rosa é erguido em mito para contrariar uma certa ideia uniformizante e modernizante de um Brasil em ascensão. O lugar distante e marginal, que é o planalto interior do Brasil, converte-se num labirinto artificialmente desordenado e desordenador.

$[\ldots]$

Há aqui um posicionamento político nunca enunciado mas inscrito no tratamento da linguagem. É na recriação da linguagem que ele sugere uma utopia, uma ideia de futuro que está para além daquilo que ele denuncia como uma tentativa de "miséria melhorada". Esta linguagem mediada entre classes cultas e os sertanejos quase não existia no Brasil. Através de uma linguagem reinventada com a participação dos componentes culturais africanos, também nós em Angola e Moçambique procurávamos uma arte em que os excluídos pudessem participar da invenção da sua História. (Couto, 2005, p.108-110)

E essa possibilidade da invenção, que passa pela possibilidade de falar da margem, que surge a epifania de escrever "diferente", de escrever sobre o meio do caminho, de usar todas as possibilidades da fala e da linguagem, e é aí que começam as similaridades entre Guimarães Rosa e Luandino Vieira. Em uma epifania, por meio da qual Luandino ganha a percepção da palavra como parte do instrumento de criação do que é a literatura. 


\section{2.}

Rios

Volto ao começo da minha questão. Em O Livro dos Rios, obra de maturidade de Luandino, escrita depois de uma ausência de quase quinze anos do mundo da criação - desde as eleições fracassadas em Angola, se afasta da escrita, excetuando-se por Kapapa -, Luandino se aprimora nesse uso da linguagem. E recorre aqui ao rio, tema caro para Guimarães Rosa, que contava as histórias de seu sertão mineiro, do sertão que segue o curso do Urucuia até chegar no São Francisco e se espalha por seus igarapés. O rio, em $O$ Livro dos Rios, é o fio condutor da história, é o que dá leveza à pesada história do menino guerrilheiro que deve se responsabilizar por matar o traidor. Ele dá à nossa história a noção de fábula. O rio é onde o menino, Kene Vua, aprendeu a vida, seguindo no barco de seu pai. Ao longo do livro, o Kwanza é o rio e é Angola, representando também a nação. Como ele fala logo na abertura do livro, e repete por diversas vezes, parafraseando Langston Hughes:

Conheci rios.

Primevos, primitivos rios, entes passados do mundo, lodosas torrentes de desumano sangue nas veias dos homens.

Minha alma escorre funda como a água desses rios.

Só que, na guerra civil da minha vida, eu, negro, dei de pensar: são rios demais - vi uns, ouvi outros, em todas mesmas águas me banhei é duas vezes.

$[\ldots]$

Digo mais: também eu, sou um rio. (Vieira, 2011, p. 97)

O leitor segue esse rio, esse narrador. Pelo leito do rio a história vai sendo criada, serpenteada por sobre a topografia de Angola. Ela reconstrói esse espaço onde existe Kene Vua, onde existem os guerrilheiros, o espaço de Luandino. Para acompanhar a história, é preciso acompanhar essa topografia, o leito desse rio, que leva o leitor a seguir a narrativa. A narrativa feita a partir do entorno, que começa pelas bordas, que não começa diretamente com a história, nos mantém afastados o suficiente para podermos perceber o que acontece. No lugar da narrativa seca e direta do musseque, quase que um retrato da miséria, a narrativa distante, até no tempo, do que acontecia na guerrilha, um relato quase memorialista. $\mathrm{O}$ relato das 
ideias e do que formou o país, das realidades e das fantasias, tendo o rio, o Kwanza, como o centro, o princípio das fantasias e realidades que criaram uma nação. Luandino nos pede aqui para interpretar o seu texto. Os seus rios guardam segredos, mostram detalhes de um pensamento que são desmembrados somente com a leitura atenta e aprofundada.

Com uma narrativa não linear e um trabalho de linguagem rebuscado, $O$ Livro dos Rios não é um livro para se ler distraidamente. Exige que nos afastemos da nossa realidade para entrarmos na realidade do rio. O rio nos carrega e nos leva para um lugar onde podemos não estar em sintonia com tudo que se passa ao nosso redor, onde podemos criar e pensar. E assim, o rio em Luandino se torna também um elemento político de sua escrita, na medida em que impõe ao leitor essa atenção e esse cuidado. O rio muda e segue, e é preciso atenção para segui-lo. E esse distanciamento da realidade, essa atenção, são também um ato político. E as histórias dos rios se misturam com as histórias dos personagens. Se Kene Vua, personagem principal, muda de nome e volta a ser o Kapapa, nome dado a ele por seu avô, por ter conseguido matar a arraia, os rios secam e mudam de nome da mesma forma. Os rios têm sangue, e cabe a nós acompanharmos as mudanças que os rios fazem nos homens e vice-versa:

\footnotetext{
Morreu um rio - simples risco de lápis azul no mapa da nossa terra, afogado em sangue, empedregou. Na carta geográfica de 1939 já não está lá. Disseram os portugueses que a culpa é da escala: um milímetro do mapa deles chega para dois milhões da terra nossa...

A ver vamos - nunca é tarde. (Vieira, 2006, p.168)
}

Luandino aqui nos mostra que, da mesma forma que homens matam homens e rios matam homens, os rios também são mortos, "empedregam", somem do mapa. O caminho vai sendo mudado, o narrador reconhece não só a mudança nele, mas em seu país. Angola foi mudando e sendo mudada pelas sucessivas guerras, assim como Kene Vua foi mudando pelos sucessivos acontecimentos violentos em sua vida. O rio aqui convida o leitor a seguir e acompanhar as mudanças. Chama o leitor para ser parte da correnteza, seguir ela, perceber a inconstância do rio. A interpretação que Luandino considera necessária também é a de se deixar levar pela história que ele conta, de Angola e de Kene Vua. Um memorial do que é Angola até hoje, pela geografia de seus rios. Como diz Chaves 
(2006), os rios nos arrastam para esse caminho, com as imagens que os descrevem:

Após as primeiras páginas, o leitor percebe que se a geografia muda, o pacto proposto por José Luandino Vieira mantém a sua radicalidade inquietante: mais uma vez, o narrador convoca-nos para uma viagem cuja marca dominante é o risco, arrastando-nos para um turbilhão de imagens e sentidos que tornam impossível qualquer hipótese de sossego. (Chaves, 2006)

O narrador aqui, Kene Vua, chama o leitor para esse risco que é a viagem pelo rio. As imagens são alinhavadas pelo rio, pelo caminho que é aberto ou fechado pelas águas e pelo sangue. O rio, assim, se torna um personagem contado pelo narrador que chama o leitor para seguir o fio da narrativa.

O rio em Guimarães Rosa também tem esse papel. De personagem mudo, mas participante, da história. Falo aqui especificamente de A Terceira Margem do Rio, onde o rio é o pai e é a loucura. O rio é o que o personagem persegue e do que ele foge. $\mathrm{O}$ rio é o que permite refletir e o que afasta do mundo. $\mathrm{O}$ pai, sem nome, vai, fica e nunca mais volta, seguindo a ordem dada pela mãe, em trecho do conto. O rio é observado e deixa o protagonista afastado de tudo ao redor. Ele se separa de amigos, de família, da cidade, para tentar entender, tentar ver o pai. Todos saem da cidade envergonhados pelo pai, e ele fica. E o pai nunca volta. Continua na canoa, no meio do rio, afastado de todo o resto, remando sem jamais voltar pra margem, sem nunca cortar a barba. E na hora da precisão, como diria Guimarães Rosa, o personagem não consegue seguir a função paterna, e foge. E pede que o deixem fazer isso na morte, que também ele seja um rio quando morrer:

Mas, então, ao menos, que, no artigo da morte, peguem em mim, e me depositem também numa canoinha de nada, nessa água que não pára, de longas beiras: e, eu, rio abaixo, rio a fora, rio a dentro - o rio. (Rosa, 1988, p. 32)

O rio então novamente é o que leva, o que cria, o que permite. Só no rio, em comunhão com este, ele pode estar novamente junto com seu pai, pode voltar a saber o que é a figura paterna. O pai que, em um momento de loucura - palavra que nunca mais se falou naquela casa - foi com a canoa para o meio do rio e lá ficou, deixando o espaço do pai livre na casa, chamando outros para tentar 
preencher esse espaço:

\begin{abstract}
Mandou vir o tio nosso, irmão dela, para auxiliar na fazenda e nos negócios. Mandou vir o mestre, para nós, os meninos. Incumbiu ao padre que um dia se revestisse, em praia de margem, para esconjurar e clamar a nosso pai o 'dever de desistir da tristonha teima. De outra, por arranjo dela, para medo, vieram os dois soldados. Tudo o que não valeu de nada. Nosso pai passava ao largo, avistado ou diluso, cruzando na canoa, sem deixar ninguém se chegar à pega ou à fala. Mesmo quando foi, não faz muito, dos homens do jornal, que trouxeram a lancha $\mathrm{e}$ tencionavam tirar retrato dele, não venceram: nosso pai se desaparecia para a outra banda, aproava a canoa no brejão, de léguas, que há, por entre juncos e mato, e só ele conhecesse, a palmos, a escuridão, daquele. (Rosa, 1988, p. 32)
\end{abstract}

O pai não volta, segue o seu dever com esse chamado, só retornando quando chamado pelo filho, já idoso. O pai que se transformou na terceira margem do rio e cortou os vínculos, sem nunca morrer. Esse pai, buscado pelo filho, que nunca sai da cidadezinha, esse pai que o filho admira apesar da loucura, é o rio, e o narrador sabe disso; nós leitores, só aprendemos depois, com o fluir do rio. Sabe que precisa se tornar um com o rio, para poder voltar a ter um vínculo com seu pai, precisa ser o rio. Que seu vínculo com a vida é o rio e que na morte se refaz o vínculo.

É evidente que o magnífico conto "A terceira margem do rio" trata de margens, delineando um rio que recorta a narrativa em dois espaços: o da casa, do terreno às margens do rio, e o de suas águas extensas, cheias de mistério, que abrem para o exterior do conto, em sua passagem inexorável e caudalosa. [...] O pai nomeia o rio, que flui e serra, rio-rio, e localiza o filho em uma de suas margens. (Rivera, 2005)

Da busca por um local, por uma possibilidade diferente de colocação no mundo, com quarenta anos de diferença entre o texto de Rosa e o de Luandino, os dois colocam a necessidade de se afastar de um espaço para poder pertencer / pensá-lo. O rio, nos dois textos, é o que o personagem se torna por desejo próprio, é preciso se tornar o rio, é preciso se transformar na metáfora. Estar no rio, ser o rio, os torna parte de algo que eles mesmos identificam: parte de Angola, no caso de Kene Vua em $O$ Livro dos Rios, parte de seu pai, no caso de A Terceira Margem. O rio é a continuidade e o afastamento que permite ao leitor a integridade e a fidelidade a si mesmo. E aqui pretendo mostrar que a influência na linguagem, assunto reiteradamente discutido quando se menciona Luandino e 
Guimarães Rosa, não é a única, a influência aqui também chega ao tema usado, e como se usa esse tema. Uma das citações, dentre muitas no texto de Luandino, é ao texto de Rosa, é ao rio que Rosa menciona. Esse rio fala de um pertencimento, de uma possibilidade de futuro. E como esse pertencimento exige para eles a distância que só o rio e o tempo podem nos dar. Porque as margens do rio são aquilo que não querem:

Nesse caso, é lícito pensar que, se há uma insatisfação com as margens do rio, a terceira margem é uma utopia e, por isso mesmo, uma esperança. de uma nova sociedade, de uma nova relação de gênero (ou, até mesmo, uma ausência dessa distinção), de uma nova cultura, de um mundo simbólico muito mais perto das relações do prazer do imaginário. (Goulart, 2004)

Esse pertencimento é algo em comum, algo que podemos ver na literatura dos dois escritores, algo além da linguagem, entrando na seara do que se fala e de que posição se fala, mais do que do simplesmente o como se fala. Os rios, a geografia, importam para a demarcação do local de fala do narrador e para delimitar essa busca de esperança no futuro. Tão importante quanto a forma de fala, o local de enunciação deixa claro que os dois escritores falam de um ponto de busca, de um ponto de criação de uma existência em mutação, e os rios são a imagem que escolheram para mostrar isso, os rios se adaptam à geografia e correm, são mutáveis como os homens, e são comuns às topografias dos dois países. Fazem parte da vida das pessoas. E a imagem de que nunca nos banhamos duas vezes em um mesmo rio ainda é muito forte, Heráclito faz parte dos fundamentos do Ocidente. Mesmo com o narrador d'O Livro dos Rios afirmando que, em alguns, ele já se banhou mais de uma vez.

\section{3. O bando}

O segundo livro da trilogia de Luandino, O Livro dos Guerrilheiros, muda de tema, mas não se afasta de Guimarães Rosa. Os rios, que contam a história de Angola, continuam presentes como a geografia já anteriormente definida do local. Kene Vua continua presente como narrador, com o seu nome de nascimento, 
Diamantinho Kinhoka, troca de nome para Kene Vua, e depois para Kapapa. Mas agora não é mais a sua história, mas a dos outros guerrilheiros que conheceu. O livro começa com esse destino claro:

Entanto que ex-guerrilheiro, eu, Diamantinho Kinhoka, ainda com a autorização que sempre a amizade e camaradagem aceitam, sendo quissoco nosso o da luta de libertação, não reivindico licença de mentir. Ainda mesmo companheiros de luta, compatriotas nados e crescidos nas mesmas sanzalas, próprias ou alheias de outra região - isto é: lá onde lhes nasceram seus entespassados - não aceito crítica por adiantar contar os seus feitos, sucedos e vidas, e mortes, quando lhes tiveram já. (Vieira, 2012, p. 11)

Falando assim, ele nos explica que não é a sua história que nos vai contar, mas a de seus amigos e camaradas, de seus companheiros. E cada um tem sua história, a de como chegou na guerrilha, e de como passou por ela. São cinco histórias ao todo, de Celestino Sebastião (Kakinda), de Tenda Rialozo; Eme Makongo, Mau Pássaro, o Mau-dos-Maus; Kibiaka, a quem chamava o Parabelo; Zapata, que eram dois, Ferrujado e Kadisu; e, por fim, Kizuua Kiezabu, o general Kimbalanganza. Cada uma conta um ponto de vista e uma travessia diferente dentro da vida, o que o fez entrar na guerrilha e passar por ela e estar ou não vivo hoje.

O caminho que eles fazem é sempre mediado pelo Kwanza, presente nas narrativas, mas aqui não é um personagem tão central quanto em $O$ Livro dos Rios. O rio aqui é um objeto sempre presente na narrativa para a história dos combatentes; eles dependem dele, mas não são ele. Cada um é indivíduo com história de começo, meio e fim, cada um chega na guerrilha de uma forma diferente, por uma razão diferente, e cada um sai transformado de uma forma diferente pelo caminho, e cada história nos é trazida de uma forma diferente. Do "desumano sangue" no início d'O Livro dos Rios para os "ossos dispersos" do final desse $O$ Livro dos Guerrilheiros, o sangue também é um rio que corre em nossas veias, como os rios são as veias de Angola, metáfora que Luandino coloca diversas vezes em seus livros.

O tema do grupo e do caminho percorrido por ele, por cada um dos diferentes indivíduos, com diferentes histórias e razões de ser, é usado por Guimarães Rosa. Para ele, como já vimos, o falar do sertão, não falar da capital, Brasília, então em construção, do Brasil que vai pra frente e se moderniza, é 
importante. É importante demarcar que o sertão existe e que os sertanejos existem. É importante contar essa história. Não deixar que ela seja esquecida, manter o sertão na vida do Brasil, mostrar um Brasil que para os habitantes das grandes cidades era então - e até hoje - inexistente, invisível.

Os caminhos que os dois grupos fazem, pelo sertão e pelo Kwanza são também os caminhos da história dos dois países. De pedaços que vão sendo esquecidos e recontados. E aqui os dois autores aparecem com a mesma força de contar a sua história. É importante que não haja uma só história, como diz Chimamanda Ngozi Adichie ${ }^{12}$ (escritora nigeriana em sua primeira aparição no evento de palestras TED Talks, em que fala que é africana, mas que sua história não é a que criaram em estereótipos), é importante que as histórias sejam múltiplas. A escritora afirma que o perigo da história única, de só conhecermos uma versão dos fatos é o de nos deixarmos levar por ela para tentar compreender o que acontece a um povo ou um país. E Luandino sabe disso:

\begin{abstract}
Em primeiro lugar, eu acho que a história é sempre importante para qualquer escritor, por muito que ele ficcione, e por muito que ele se distancie daquilo a que se chama realidade para elaborar universos ficcionais, que aparentemente não tem nada a ver com a história. (Vieira, 2010, p. 189)
\end{abstract}

Os escritores precisam contar a sua história e, nos dois casos, são versões necessárias para eles, política e pessoalmente. É a história dos seus países que está sendo recontada por outras pessoas, mas também é a história deles, é o caminho deles. Os dois declaram. Novamente, a união dos temas ocorre porque são temas importantes para os dois autores. Um país que desaparece soterrado pela mola mestre do progresso em Rosa. Um país que é esquecido por quem veio depois, que coloca um passado de luta em xeque para Luandino.

O tema, somado com a linguagem, permite a reflexão sobre isso. A linguagem impõe um ritmo ao texto que é necessário para que essa história apareça. Para que se entenda de onde ela vem e que não se acredite na narrativa única e sim nas múltiplas possibilidades que a própria narrativa oferece. A linguagem força a seguir o caminho da narrativa, e em Luandino e em Rosa uma depende da outra para funcionar, linguagem e narrativa são interdependentes.

12 ADICHIE, Chimamanda Ngozi. Vídeo encontrado no site TED http://www.ted.com/talks/chimamanda_adichie_the_danger_of_a_single_story?language=pt-br 
Ao se aprofundar cada vez mais no trabalho de criação de sua linguagem para criar seu universo de histórias, Luandino acaba por se aproximar cada vez mais não só do trabalho de neologismos de Rosa, mas também dos temas por Rosa escolhidos, os temas do caminho e da jornada. O rio ou o grupo de companheiros são duas formas de mostrar esse caminho. Um pela via do rio que segue e leva o leitor a seguir o seu caminho. O outro mostrando a jornada pessoal de cada um e como essas jornadas se unem em um propósito, afinal, uma jornada tem um fim pretendido, mesmo que não alcançado.

Em O Livro dos Guerrilheiros, Luandino também cita A Terceira Margem do Rio, ao nos mostrar nessas jornadas pessoais a força que os rios têm de criação do novo. O rio como figura paterna sempre aparece, o rio como o criador de Angola:

Uma criança, da margem dos ximbicadores, viu uma criança igual, da margem dos construtores. E desobedecendo a quijilas, proibições e surras de seus mais-velhos, nadou para o meio do rio; e a outra criança igual, da margem dos construtores, pôsse a falar com ela e se meteu a nadar até se darem encontro. Na futura margem do rio. Perceberam então, todos os seus mais-velhos, que era chegado o tempo da coragem. E se levantou aí, numa manhã, esse tempo novo, uma nova idade na nossa terra (Vieira, 2009, p. 974)

Aqui, como em Rosa, as margens são os mais velhos. Mas quem cria a terceira margem não é o pai. O pai fica na margem, e os filhos vão ensinar a todos como criar esse novo caminho pelo rio. A questão para Luandino não era, como em Rosa, a preservação do que está se perdendo e a necessidade de se carregar o passado para se fazer o futuro, a memória. Em Guimarães Rosa, a terceira margem é o pai, é ele quem permanece sempre no meio, seguindo ali a ser parte do rio, em tarefa que, tudo indica, será passada adiante, mas não é. O filho foge à obrigação, sem nunca esquecer o passado, de sua história e do pai, e com a possibilidade futura de retomar essa posição. Para Luandino, a questão é o novo, como o novo se cria e a necessidade de criá-lo. É a nova Angola que pode nascer a partir da união das duas crianças, que também elas criam uma terceira margem do rio. Mas essa terceira margem é de possibilidade de futuro, não de permanência. É de quebra e de novo começo, é um tempo novo que surge, não na manutenção do tempo antigo e de aceitação dos ideais paternos. O rio, essa terceira margem, é a esperança, é o que precisa ser construído ainda, enquanto que em Rosa ela é o que 
sempre esteve ali. E não a terceira margem da responsabilidade de continuidade:

\begin{abstract}
Minha irmã se mudou, com o marido, para longe daqui. Meu irmão resolveu e se foi, para uma cidade. Os tempos mudavam, no devagar depressa dos tempos. Nossa mãe terminou indo também, de uma vez, residir com minha irmã, ela estava envelhecida. Eu fiquei aqui, de resto. Eu nunca podia querer me casar. Eu permaneci, com as bagagens da vida. Nosso pai carecia de mim, eu sei - na vagação, no rio no ermo - sem dar razão de seu feito. Seja que, quando eu quis mesmo saber, e firme indaguei, me diz-que-disseram: que constava que nosso pai, alguma vez, tivesse revelado a explicação, ao homem que para ele aprontara a canoa. Mas, agora, esse homem já tinha morrido, ninguém soubesse, fizesse recordação, de nada mais. Só as falsas conversas, sem senso, como por ocasião, no começo, na vinda das primeiras cheias do rio, com chuvas que não estiavam, todos temeram o fim-do-mundo, diziam: que nosso pai fosse o avisado que nem Noé, que, por tanto, a canoa ele tinha antecipado; pois agora me entrelembro. Meu pai, eu não podia malsinar. E apontavam já em mim uns primeiros cabelos brancos. (Rosa, 1988, p.32)
\end{abstract}

Outro ponto que podemos perceber em comum nos pequenos detalhes é a questão do nome dos guerrilheiros em Luandino. Especificamente Kene Vua, que é o Kapapa, que é o Diamantinho Kinoka. Também Riobaldo, personagem principal de Grande Sertão: Veredas, quando entra para o cangaço, passa a se chamar Tatarana; ao assumir a chefia do bando, é Urutu Branco. Os nomes mudam de acordo com seus caminhos, com as necessidades que eles têm de preencher um papel diferente em suas jornadas, como em $O$ Livro dos Guerrilheiros, quando Kene Vua fala de suas mudanças:

Ouvi então o cheiro do mar, maré de repente, naquelas águas barrentas de rio verde - eu era o Kapapa de novo, o guerrilheiro Kene Vua s'afogara em meu corpo salgado, cheio daquele cheiro de sol e mangue, o vento das salgas que fui nascido com ele. E isso nenhuma mata ia poder nunca lavar, era catinga de geração. (Vieira, 2011, p 218)

A trilogia de Luandino não é uma releitura da obra de Guimarães Rosa. Mas trabalha com delicadeza temas e questões que eram caros ao mineiro: o tema da busca, da jornada e o da história. A história é sempre importante e presente como resgate e criadora de futuro. Mais uma vez, usando a fala de Chimananda, a existência de múltiplas visões do que é essa história, inclusive pelo viés da ficção, é importante para que a construção de um futuro. Porque é a partir das múltiplas identidades, da diversidade que se pode forjar um caminho de inclusão. Ver o 
presente e o passado por diferentes pontos de vista e caminhos ajuda a construir um melhor futuro, um futuro em que a utopia de um mundo com uma maior igualdade entre os homens, é possível. 


\title{
4 \\ O futuro do pretérito
}

\begin{abstract}
E também, outrossim, porque é dos livros da memória e tradição no nosso povo que aquele com quem tens de comer as folhas do macunde na tribulação, tem de ser aquele que repartes com ele o feijão na abundância. Daí que a verdade de suas vidas sempre não é possível de escrever, ainda que desejada; mas, menos ainda, desejada se possível. A gente fizemos a revolução, nossas memórias têm o sangue do tempo.

Se os verdadeiros escritores da nossa terra exigirem a certidão da história na pauta destas mortes, sempre lhes dou aviso que a verdade não dá se encontro em balcão de cartório notarial ou decreto do governo, cadavez apenas nas estórias que contamos uns nos outros, enquanto esperamos nossa vez na fila de dar baixa de nossas pequeninas vidas.
\end{abstract}

(José Luandino Vieira, O Livro dos Guerrilheiros)

\section{1.}

\section{Luandino e seus romances}

Nos primeiros textos do escritor, podemos perceber as tintas carregadas do que Calvino chama de dever de representar sua época: "Começarei por esse último ponto. Quando iniciei minha atividade literária, o dever de representar sua época era um imperativo categórico para todo jovem escritor" (Calvino, 1990, 1516). O autor na época precisava deixar clara a sua intenção, representar o que via. Luandino participou dos primeiros momentos do MPLA (Movimento Para a Libertação de Angola), movimento depois transformado em partido, que lutou pela libertação de Angola. O escritor participou dessa luta mostrando a realidade de uma Angola colonial, subjugada pelos interesses da metrópole. A partir do momento em que, preso no Tarrafal entra em contato com a literatura de Guimarães Rosa, e começa a perceber que pode não só relatar, mas também usar em seus relatos a língua falada em Angola. E, com isso, adiciona mais um nível de denúncia em seu discurso de luta política. Como já foi citado nesta dissertação, o autor viu na escrita do autor brasileiro a possibilidade de mais um elemento da criação, uma vez que, para Portugal, era imprescindível a manutenção do português castiço falado na metrópole como ferramenta de dominação colonial. A denúncia, a crítica da falta de atenção, da ignorância de Portugal sobre o que é Angola. Não só sobre as violências, mas sobre questões culturais básicas. O 
regime colonialista de então não conhece e não quer conhecer Angola com uma identidade própria mas apenas a extensão de Portugal, uma província ultramarina, uma parte, e não um país com cultura separada. Não há fronteiras no Império Português, todas as províncias ultramarinas são iguais como dizia a propaganda salazarista.A descrição de António Lobo Antunes talvez revele melhor essa dificuldade de entender o outro amplificada pelo domínio colonialista:

\begin{abstract}
O meu pai costumava explicar que aquilo que tínhamos vindo procurar na África não era dinheiro nem poder mas pretos sem dinheiro e sem poder algum que nos dessem a ilusão do dinheiro e do poder que de fato ainda que o tivéssemos não tínhamos por não sermos mais que tolerados, aceitos com desprezo em Portugal, olhados como olhávamos os bailundos que trabalhavam para nós e portanto de certo modo éramos os pretos dos outros da mesma forma que os pretos possuíam os seus pretos e estes os seus pretos ainda em degraus sucessivos descendo ao fundo da miséria, aleijados, leprosos, escravos de escravos. (Antunes, 1999)
\end{abstract}

Em Luuanda a representação do país ainda é de uma Angola presa a Portugal, mesmo que nesse livro Luandino comece a criar uma narrativa que denuncia a exploração e o domínio colonial através das histórias e da linguagem. Ele deixa claro que a linguagem é seu campo de luta. Luuanda foi o ponto de partida para experimentações e criações com a linguagem, que perduraram até Nós, os do Makulusu, seu último livro antes de se afastar momentaneamente da literatura, cada vez de forma mais engajada com a mudança da linguagem. Na volta ao mercado editorial depois de tanto tempo, com a trilogia De Rios Velhos e Guerrilheiros (da trilogia foram publicados apenas dois livros, fica faltando o terceiro volume), ele se aprofunda ainda mais na questão da linguagem e como que se afasta da denúncia de fatos do cotidiano angolano, de forma paradoxal, Luandino cria dessa forma uma leveza, nos moldes do que Calvino tenta sugerir em seu ensaio em Seis Propostas para o próximo Milênio. Uma das questões de Calvino no livro é a mudança de ponto de observação:

Cada vez que o reino do humano me parece condenado ao peso, digo para mim mesmo que à maneira de Perseu eu devia voar para outro espaço. Não se trata absolutamente de fuga para o sonho ou o irracional. Quero dizer que preciso mudar de ponto de observação, que preciso considerar o mundo sob uma outra ótica, outra lógica, outros meios de conhecimento e controle. As imagens de leveza que busco não devem, em contato com a realidade presente e futura dissolver-se como sonhos... (Calvino, 1990, p. 19) 
São imagens que, com o auxílio da linguagem, diluem o peso dos acontecimentos, e a leitura, apesar de continuar difícil, se torna menos pesada. São diversos níveis de leitura que se inscrevem. A história do menino que é um dos guerrilheiros, que mora no meio dos rios de Angola, passando entre sanzalas, se dilui entre fantasias e digressões sobre os rios, ou melhor dizendo, com a sua história de Angola, essas imagens, que não são sonhos, mas fantasias, mudam o ponto de observação. Logo na epígrafe, Luandino Vieira nos dita o tom da sua narrativa:

\footnotetext{
"In dubio cronichae, pro fabula..."

dizem que disse - assim mesmo, em latim - Njinga Mbandi, rainha, a Antonio de Oliveira Cadornega, historiador, na comprovada presença de Frei Giovanni Antonio di Montecúccolo, o Kavazi. Na nossa cidade de Santa Maria da Matamba, aos dezessete dias do mês de Dezembro de 1663, dia de Santa Olimpia Viúva. (Vieira, 2006, p. 11).
}

Luandino nos deixa aqui, pelas palavras da Rainha Njinga, mitológica líder de resistência angolana, o testemunho de que, para ele, interessa a fábula, a invenção, a história contada, e não a outra, qualquer que seja a outra, da crônica histórica. Essa é a sua Angola, a que lhe interessa, e ele o diz nessa epígrafe sem autoria, ou antes com autoria relatada por cronistas e pela fábula. E ele mistura e tece uma rede onde as realidades se confundem.

Assim, o menino, Kene Vua, também é rio. E esse ser rio, essa fuga pela fantasia, dá leveza a toda a história, pesada, da descolonização de Angola. Aqui esse processo é contado como fábula da história de um personagem, de um grupo de personagens, e não mais como o que era feito em Luuanda, com a representação de seu tempo. Vemos idas e voltas da história, Kene Vua em sua discussão interna sobre suas funções na guerrilha - no momento em que começamos o livro, sua questão é matar um traidor - se intercalar com as descrições e as histórias de vida dos rios de Angola. Porque aqui os rios não são apenas locais. São também personagens. Eles têm vida e força, contam suas próprias histórias, nascem, crescem e morrem, de acordo com a história de Angola como nos é contada. Na sua sequência, O Livro dos Guerrilheiros, a linguagem nos ajuda a criar um mundo confuso, em que a fábula e o documentário Luandino fala no nome de guerrilheiros que teriam participado da guerra civil 
angolana - se misturam e criam uma só história, em que a ficção não ocupa um lugar claro.

O Livro dos Rios começa a narrativa colocando em causa o seu objeto. O livro é como um romance-tese no qual Luandino Vieira defende a sua visão da guerrilha, e a sua visão de uma utopia de igualdade. Ele começa com a descrição dos rios de Angola, que serão identificados como o cenário. Após a epígrafe citada nos colocar no mundo da fábula, o livro se inicia com uma citação do poeta Langston Hughes, de quem diz o livro ser um "retribute", a retribuição, um tributo, uma homenagem. Sua adaptação muda um detalhe, o sangue, no original em inglês, é human, humano, e em sua adaptação, o sangue se torna desumano. $O$ Livro dos Guerrilheiros começa por colocar de quem está falando. Diretamente, já na dedicatória, a um guerrilheiro real, morto na guerra de libertação, símbolo da juventude angolana, diz sobre o que quer falar. E segue falando sobre essa parte da história de Angola, fazendo um jogo com o leitor: o texto que lemos teria sido encontrado no bolso de um guerrilheiro morto ao mesmo tempo em que seriam os planos para um documentário. $\mathrm{O}$ autor utiliza vários níveis da escrita nesse caso (no bolso de um guerrilheiro morto) ele faz referência a Fernando Pessoa, no poema "O menino de sua mãe"13. - O menino da sua mãe/ Jaz morto e arrefece/ Caiu-lhe da algibeira/A cigarreira breve:

Melhor é transcrever as mucandas.

Assim, a primeira: papel dobrado em quatro, sem rasgo ou rasura de humidade ou óleo de comida ou espingarda, só aperreado de tantos meses de solidão nos bolsos dum camuflado. Pelos vincos e dobras, essas rugas do tempo, se vê bem que saiu no bolso esquerdo, do lado do coração. Dizia, e reescrevo: (Vieira, 2011, p. 68)

Dois livros, duas partes de uma trilogia, que falam de Angola. De uma narrativa da independência e da história de seu país. Segue assim contando histórias de vida de cinco guerrilheiros (seis na verdade porque dois deles formam apenas um), cinco personagens das lutas. Cada capítulo leva o nome de um guerrilheiro. E um nome, o Zapata, fala de duas pessoas, que se apresentavam como uma só:

\footnotetext{
${ }^{13}$ PESSOA, Fernando, Obra Poética em um volume, Rio de Janeiro, Companhia José Aguilar Editora, 1969, p146.
} 
E estes eram os camaradas que sempre queriam estar juntos, numa amizade lá muito deles mesmos. De pé; em formatura de bandeira ou revista; sentados, sem tarefa ou em missão, descanso ou comida; em emboscada, lado a lado; deitados, no sono. Sonhavam juntos. Viviam assim, conjuntados. Tudo se repartiam, mesmo nódoa de seu simples pingo de café. E queriam se chamar de um só nome de guerrilheiro: Zapata. Porquê, só mesmo nosso comandante Ndiki Ndia podia saber. (Vieira, 2011, p. 554)

O Zapata são dois amigos tão unidos que atendem por um nome só. $\mathrm{O}$ autor descreve cada nome de guerrilheiro em um capítulo e narra suas histórias. E Zapata é só uma história.

\section{2. Rancière e a história em Luandino}

Como pode ser visto na epígrafe deste capítulo, Luandino não considera a história uma forma confiável ou mesmo a única possível. A história é sempre uma versão dos fatos. Era vista na Grécia antiga como próxima à poesia, ao que nos deixa imortais, nos difere das coisas. Nossa capacidade para ser relatados e para relatarmos. A criação da coisa. E a história, como a poesia, é artefato criado pelo homem. Rancière, em sua entrevista transformada no livro A Partilha do Sensível fala que "O real precisa ser ficcionado para ser pensado" (Rancière, 2009, p. 58). Usa em seu texto como exemplo um documentário de Chris Marker, e a necessidade e possibilidade que esse documentário tem de remontar, de mudar a narrativa a partir da manipulação dos fatos. Marker joga com diferentes combinações de documentos para contar parte da história da Rússia tzarista. Ele faz do ficcional e do documental instrumentos iguais para relatar a história que quer contar sobre a Rússia.

Em sua trilogia - ao menos nos dois romances já publicados até hoje Luandino faz como Chris Marker. Ele coloca em seu texto documentos da história de Angola e ficções fabulosas. Ele fala de coisas que ocorreram, como a guerrilha, a luta pela libertação de Angola, nas palavras de Agualusa: 
A República Popular de Angola nasceu debaixo de fogo. Quando às zero horas e vinte minutos do dia 11 de Novembro de 1975 o Presidente Agostinho Neto proclamou formalmente a independência daquela que fora, até então, a joia do império português, já a guerra se alastrara a todo o território. (Agualusa, 2004)

A partir disso, Luandino cria seu mundo, cria sua narrativa. Ele ficcionaliza a história de seu país para poder pensá-la. Como Rancière enfatiza,

A política e a arte, tanto quanto os saberes, constroem "ficções", isto é, rearranjos materiais dos signos e das imagens, das relações entre o que se vê e o que se diz, entre o que se faz e o que se pode fazer. (Rancière, 2009, p. 59)

Política e arte, para Rancière, são ficções, rearranjos, a ficção, como forma artística, é também uma possibilidade desses rearranjos, para se relatar e mostrar essas relações. Luandino tem consciência de que está escrevendo a sua versão dessa história, contando o seu universo dentro dessa história. Aqui cito um trecho de Luandino em entrevista dada a Joana Passos, respondendo sobre a ligação de sua escrita com a crônica histórica, como relato do passado de seu país:

Em primeiro lugar, eu acho que a história é sempre importante para qualquer escritor, por muito que ele ficcione, e por muito que ele se distancie daquilo a que se chama realidade para elaborar universos ficcionais, que aparentemente não têm nada a ver com a história. No caso de Angola e dos Angolanos ainda com maior pertinência, porque por um lado, durante o período da ocupação, da conquista, do colonialismo, e mesmo depois, houve sempre a tentação de apagar a história do território e a história das pessoas que aí viviam, e mesmo existindo uma vasta documentação relativa a essa história, essa documentação não está ao alcance dos angolanos, está espalhada por arquivos na Holanda, em Portugal, na Santa Sé, etc... [...] Por outro lado, alguns dos autores que escrevem a literatura moderna de Angola, eles próprios participaram numa fase da história de Angola que é mais visível e conhecida, e torna-se imprescindível, se quisermos construir uma ficção que tenha como contexto o que se chama Angola, de um ponto de vista que inclua esse conceito que se criou/gestou nos anos quarenta, de angolanidade, é imprescindível conhecer a história, ou privilegiar o conhecimento histórico, ou inventar a história como quadro para a ficção. [...], mas a história é uma outra forma de ficção, pois a história é escrita por humanos. No entanto, a escrita ficcional não obedece a pressupostos históricos, nem se pretende deixar a história de Angola acrescentada ou diminuída. A parte histórica é ditada pelo peso que a realidade, ou a visão que eu tenho da realidade objectiva, tem na minha ficção. Não sou capaz de efabular fora de um quadro histórico, porque também não fui capaz de viver a minha própria vida e a minha experiência fora de um quadro histórico. (Vieira, 2010, p. 189-190) 
Luandino portanto percebe que a ficção tem papel de criação da história também, e nessa ficção, Luandino nos coloca clara outra questão vista em $A$ Partilha do Sensível. A literatura é parte da política tanto quanto da cultura, porque em seus enunciados permite perceber que as duas são ficções. Ficções que criam sujeitos políticos, que colocam a partilha desse sensível em causa explicitamente, ao colocar o corpo coletivo em causa. Como na Europa do século XIX, na Angola da década de 60 do século passado, essa questão estava presente, do corpo coletivo, dessa heterotopia possível, como chama Rancière. Até aqui discutiu-se ficção. Uma ficção que aponta para o que era o real almejado de Angola, nos anos 60, a independência. Angola fez a guerra para se tornar um país separado de Portugal. A ficção do autor é calcada no "real", em eventos fatctuais da História de Angola. É em cima dessa história que ele cria uma história possível e desejada.

O "real” só pode ser alcançado por alguma intermediação, diz Hal Foster, pois o homem é o que vê o "por trás" e esse por trás seria o "real". O homem, como diz Lacan, é o que precisa do véu, do intermediário, para ver o objeto, a realidade. Esse real é chamado por Foster de trauma, o que não se pode alcançar, pois para Lacan, tal como o real, o evento traumático em si não pode ser acessado, mas somente repetido, para que seja elaborado. Luandino aqui faz essa intermediação. Ele coloca nesses dois livros o que pode chamar de trauma coletivo de Angola, a guerra. E repetindo a guerra, recontando a história de outra forma, procura nos dar acesso a esse acontecimento, a esse "real".

Se Luandino usa a ficção para pensar esse "real", ele não o faz já processado, ele convida seu leitor a fazer o mesmo pensando, relendo e repetindo, obrigando a elaborar e a refletir sobre o que está lendo. Convida a pensar sobre Angola e sobre sua geografia e história. Toda história é contada, é ficcionalizada, toda história tem seu viés, sabemos, e o mesmo foi reiterado por Rancière, ao dizer que política e arte constroem "ficções". O escritor se coloca como parte da vivência histórica. A história de Angola também é parte dele, portanto. A história oficial de um país tem tanto de ficção quanto a política ou a arte. Até por ser um produto das duas.

Luandino ficcionaliza e relata a sua história de Angola, seu relato, impregnado dos acontecimentos, dos "traumas" que fazem parte da criação do 
país. Mas faz isso reelaborando ao seu modo, quer dizer, a história é contada por ele de forma ficcional e de forma a falar das questões e dos traumas que o interessam, do que para Luandino foi esse momento histórico de seu país, do qual ele fez parte.

Ao ler o livro, com essa forma ficcionalizada da história, nos vemos transportados para uma leveza, como diria Calvino, que só é permitida pelo ficcional. Essa capacidade e possibilidade de nos atermos ao mundo da fantasia, da fábula, nos permite encarar com mais leveza o relato de uma guerra, nos permite tentar acessar esse trauma. Não com uma leveza absoluta, que o assunto não permite, mas com a possibilidade da fabulação e da criação, não de um sonho mas de uma literatura, de uma possibilidade de leveza como reação. Cito Calvino: "Resta ainda aquele fio que comecei a desenrolar logo ao princípio: a literatura como função essencial, a busca da leveza como reação ao peso do viver." (Calvino, 2002, p. 39)

Com essa visão e método de ficcionalizar, talvez pensar sobre o "real" de Angola se torne mais profundo do que com as ficções iniciais de Luandino, que relatavam os acontecimentos de uma forma mais próxima, usando um tom menos próximo ao da fábula, talvez $O$ Livro dos Rios seja o caminho de via longa. Em Luuanda, um de seus primeiros livros, e o primeiro onde começa a criar também com a linguagem, as três histórias são lineares, descrevendo acontecimentos de opressão cotidianos dos angolanos sob o jugo português, é quase panfletário. A utilização da linguagem aqui vem como resistência ao domínio da metrópole, junto com os relatos de três histórias com personagens, cenário e linha do tempo claras. Isso vai se modificando em Luandino, até o começo de sua trilogia, quando a linguagem se torna praticamente mais um personagem, quando ela nos dá o ritmo de todo o processo, uma linguagem poética, portanto. $\mathrm{O}$ relato feito nesses dois livros é um relato não linear, de um passado aparentemente distante, contado como uma fábula, começando pela adaptação da poesia em $O$ Livro dos Rios e pela dedicatória ao guerrilheiro real em $O$ Livro dos Guerrilheiros. Com isso ele nos convida a entrarmos na fábula e, ao mesmo tempo, a buscarmos as citações ele não nos tranquiliza. Na verdade, em sua partilha, no pedaço que ele escolheu, ele recoloca e problematiza a política como inserção e a arte como atividade humana. Incluindo aí a literatura. Ele discute aí a formação como país, como antes ele relatava a luta que era necessária. Aqui a luta se passa no passado, o que já 
houve, por mais que o resultado dessa luta e desse passado permaneçam no presente. E que ele direcione em certo momento para nos dizer que a luta deve continuar. E esse presente, imprensado pelo passado e pelo futuro, que borra a fronteira do tempo.

Hannah Arendt coloca esse espaço entre o passado e o futuro, essa encruzilhada do homem, como sendo espaço de pensamento, um fenômeno mental. Esse ponto do fenômeno mental, esse lugar de produção de discurso, é o lugar em que se coloca Luandino em sua trilogia. O lugar do homem, de pegar os retalhos e com isso poder construir o espaço da fábula e do onírico.

\section{3. \\ O sonho, o futuro, o "real" em Luandino}

Podemos então falar que a história da trilogia entra aqui como uma fábula, anunciada desde sua epígrafe. Um sonho do real almejado nos anos 60. Da guerrilha que produziria um país inteiro, pessoas inteiras e conscientes. A Angola do futuro, da independência, já existe, mas não se consolidou como a utopia sonhada. É um país reconhecido politicamente, com produção econômica e cultural independentes - prova dessa capacidade de produção cultural independente é a existência de uma novela, Windeck - Todos os Tons de Angola, sendo transmitida atualmente pela Rede Brasil, ou seja, sendo exportada. A luta de Luandino não se interrompe, no entanto. Ela se transforma, se coloca em outro lugar. A utopia almejada agora é uma Angola de fábula, um tempo que passou e ao mesmo tempo ainda pode estar por vir. Nesse tempo, precisamos afirmar a posição política e participar, porque a omissão pode ser mais nociva que a ação ainda que equivocada. A utopia do homem como o agente das mudanças, mudanças éticas, mudanças estruturais. Se o homem é o lobo do homem é também o homem quem muda os rios, e o homem. A história e a geografia existem pela ação do homem. É ele que pode modificar o presente e o futuro - e mesmo o passado, uma vez que a história é um relato, similar à poesia. Luandino aponta ao fim de $O$ Livro dos Guerrilheiros que ainda há luta pela frente: 
Quando, às vezes, ponho diante de meus olhos aos grandes errores e tribulações, aos muitos sofrimentos que por nós passaram e vejo a figura de tantas vidas, e não menos mortes, no livro da nossa luta, pergunto saber: vivem, nossos mortos, se vivos os vejo em meus sonhos? (Vieira, 2011).

A fantasia entra aqui como o agente dessa mudança possível do "real”. É por meio dela que podemos recordar. É por meio da fantasia que podemos repetir o trauma, recontar o evento traumático, e é por meio dela que Luandino nos permite pensar no "real". A fantasia aqui entra como criadora, portanto, da utopia. Não da mesma utopia existente nos anos 60. Mas de uma utopia similar, que pede que nos coloquemos de outra forma no mundo. Os personagens, os guerrilheiros, dos dois livros, mudam de nome. Têm suas identidades modificadas pela história, constantemente. Quando o personagem muda o nome, ele também se torna outro. Há razões para isso, sempre. Nas histórias que nos são contadas, razões ligadas à guerrilha, ao trabalho de tornar o seu país independente, razões espirituais, ligadas aos rios.

Toda essa atmosfera de sonho é reforçada em $O$ Livro dos Rios com trechos em que Kene Vua fala da jamanta-negra (arraia que voa dentro do mar), o ser místico que traz a morte em si. A jamanta-negra aparece, como Kene Vua, o narrador das histórias contadas por Luandino, desde Kapapa, eles ali já começam a cumprir seu papel de criação da fábula e fantasia para inserir a possibilidade de leveza. É ao matar essa jamanta que Kene Vua recebe o nome de Kapapa, pois domina a morte. Com seu novo nome, Kapapa o que domina a morte, ele pode contar sua história, mas agora do seu ponto de vista.

Kapapa eu sou, hoje diante de mim: esfrego meus olhos ensonarados - minhas vidas não me dão berrida, não me cuatam. Nesta, só os fuzileiros contam os grãos de areia da pegada que a maré não quis arredondar, meu passado sempre está no altar da frente da casa do meu corpo, meu dilombe onde que brilham de vavô suas catanadas, de meu pai um cigarro apagado no escorregar do quimbundo em peleja de jacob com o anjo português, rio abaixo, mar acima. Que o futuro é o que vem atrás, me persegue sempre, nossa luta - um dia, sei, vai me agarrar: morrerei. (Vieira, 1998, p. 46-47)

Ao longo dos livros, Luandino reforça mais e mais sua intenção de reescritura da história, de inserção de uma leveza sua na história original, forjada na guerra e no colonialismo. O pós-colonial aqui entra como a possibilidade de 
construção ainda desse país, por meio da reconstrução desse passado. Um passado, como discutido por Mbembe (2001) em seu artigo As Formas Africanas de Auto-Inscrição, em que três fatos históricos relevantes se passaram na África: a escravatura, o colonialismo, e o Apartheid. E esses três fatos deixaram marcas até hoje, em diferentes partes da vida africana, levando a diferentes formas de se pensar a África:

No centro dessas duas correntes de pensamento repousam três eventos históricos: a escravidão, o colonialismo e o apartheid. A estes eventos, um específico conjunto de significados canônicos foi atribuído. Primeiro, a ideia de que, através dos processos de escravidão, colonização e apartheid, o eu africano se torna alienado de si mesmo (divisão do self ). Supõe-se que esta separação resulta em uma perda de familiaridade consigo mesmo, a ponto de o sujeito, tendo se tornado um estranho para si mesmo, ser relegado a uma forma inanimada de identidade (objetificação). Não apenas o eu não é mais reconhecido pelo Outro, como também não mais se reconhece a si próprio.

O segundo significado canônico tem a ver com a propriedade. De acordo com a narrativa dominante, os três eventos citados acarretaram a ausência de bens, sendo assim um processo no qual os procedimentos econômicos e jurídicos levaram à expropriação material. A isto se seguiu uma experiência singular de sujeição, caracterizada pela falsificação da história da África pelo Outro, o que resultou em um estado de exterioridade máxima (estranhamento) e de "desrazão". Estes dois aspectos (a expropriação material e a vio- lência da falsificação) são considerados os principais fatores que constituem a singularidade da história africana, e da tragédia na qual ela se baseia.

Finalmente, a ideia da degradação histórica. A escravidão, a colonização e o apartheid são considerados não só como tendo aprisionado o sujeito africano na humilhação, no desenraizamento e no sofrimento indizível, mas também em uma zona de não-ser e de morte social caracterizada pela negação da dignidade, pelo profundo dano psíquico e pelos tormentos do exílio. Em todos os três casos, supõese que os elementos fundamentais da escravidão, da colonização e do apartheid são fatores que servem para unificar o desejo africano de se conhecer a si mesmo, de reconquistar seu destino (soberania) e de pertencer a si mesmo no mundo (autonomia). (Mbembe, 2001)

Ao introduzir a história da guerrilha e da independência na história fantástica do menino que muda de nome e dos rios, ao colocar guerrilheiros dando entrevistas em uma história que coloca em dúvida exatamente o que está acontecendo, apesar de garantir que os guerrilheiros são personagens não fictícios, ao contar a história dos guerrilheiros como eles queriam que fosse contada - dois guerrilheiros que são um, o parabelo, o outro o general. A fantasia com que Luandino lida com os acontecimentos de Angola nos afasta da história e ao mesmo tempo não nos deixa em posição apenas de assistir. Há um chamado para participar, pensar, identificar os relatos, até mesmo a procurar pela geografia 
fluvial, ou pela biografia dos guerrilheiros. Mas o que mais podemos encontrar nas referências? O que mais podemos analisar em sua fantasia? Rita Chaves escreve sobre essa dimensão do romance de Luandino, sobre a necessidade de estarmos sempre repensando o que ele nos diz:

Ao fazer do movimento o elemento central da estratégia narrativa, Luandino radicaliza as suas propostas e nos oferece um texto denso, que cobra do leitor uma atitude contrária àquela que costuma atender aos mecanismos do mercado, sempre ávido de leitores aderentes, dóceis, cooptáveis. Apesar de curta, o que pode até levar ao questionamento do estatuto de romance que lhe reconhecemos, a narrativa interdita a hipótese de leituras rápidas, assim como recusa a proximidade com qualquer aspecto exotizante que às vezes se espera dos produtos culturais provenientes do continente africano. (Chaves, 2006, p. 252)

Luandino conta com a trilogia e com o Kapapa a sua versão da história de Angola. Ele cria uma fantasia, com o narrador Kene Vua, que passa pelos rios e pelos companheiros do narrador. Essa fantasia leva o texto por um caminho entre o fato histórico e a fábula, uma leitura que nega a velocidade, que pede a leitura lenta, mas se a história é encoberta, a leitura é minuciosa e precisa nas palavras. Calvino, em sua palestra sobre a leveza, reforça o papel da fantasia e da precisão como criadoras de leveza. Como algo que nos tira do dia a dia para nos fazer tirar os pés do chão. Cita Kafka. Aqui eu falo de Calvino. O seu visconde partido ao meio é uma alegoria do homem que não sabe o que fazer ao se ver entre dois mundos. O homem que tem dois lados, que não consegue unir seus dois lados. Kene Vua, o narrador dos três livros, sabe que ele também é um rio, que deve seguir com ele e não lutar contra, que a guerrilha e a mudança acontecerão em Angola, como as entrevistas com os guerrilheiros mostram, como a vida dos guerrilheiros continua a mostrar. Mas Kene Vua segue, sai dos rios e nos narra os guerrilheiros, continua a narrar Angola, agora não só pela sua vida nos rios. E o leitor é chamado a seguir junto a sua história, percebendo que a fantasia e o rio colocam longe o peso da mudança, sem com isso afastarem a mudança. É como o ponto exato de inflexão para que o texto conte a história sem que a história soterre. 


\section{5 \\ Conclusão}

Ao longo desta dissertação quis demonstrar como, em Luandino, a política e a sua escrita se imbricam, e como a linguagem utilizada por ele tem papel preponderante nessa marcação, mas não só ela. Ao longo de sua vida, a linguagem ganha cada vez mais força, mas também as histórias mudam o seu enfoque, possibilitando outra forma de abordar a mesma questão: o futuro de Angola.

Luandino Vieira chegou a Angola ainda criança e escolhe este país como seu. "A sua identificação com a cidade de Luanda é alvo de indisfarçada paixão e presença muito significativa nos seus textos, de tal modo que mudou o próprio nome: José Mateus Vieira da Graça torna-se José Luandino Vieira" (Edmundo, 2010). Se engaja na luta pela libertação, e é preso por isso, ao ler uma lista de desertores na rádio BBC. O período em que passa preso, Luandino descreve como período de reflexão. Um período em que pode entrar em contato com outras literaturas e culturas e escrever. E o contato com essas literaturas muda sua escrita quase que imediatamente. Como descreve Agualusa, por uma epifania. Como descreve Luandino:

E então aquilo foi para mim uma revelação. Eu já sentia que era necessário aproveitar literariamente o instrumento falado dos personagens, que eram aqueles que eu conhecia, que me interessavam, que reflectiam - no meu ponto de vista - os verdadeiros personagens a pôr na literatura angolana. Eu só não tinha ainda encontrado era o caminho. [...] Eu só não tinha percebido ainda, e foi isso que João Guimarães Rosa me ensinou, é que um escritor tem a liberdade de criar uma linguagem que não seja a que os seus personagens utilizam: um homólogo desses personagens, dessa linguagem deles. (Laban, 1980, p. 27)

Assim, fica claro como, para ele, as formas da linguagem fazem parte da história como os personagens e o que ele quer mostrar - esse futuro pretendido e utópico de Angola. Uma utopia de país, de futuro, um local de igualdade e de liberdade para o angolano. E um angolano como um ser independente e autônomo em relação ao português, que no entanto mantêm a língua portuguesa como despojo de guerra: 
Por outro lado, é talvez em Angola que o idioma, quer em sua norma culta, quer no dia a dia, venha passando por processos de apropriação mais criativos, com a incorporação livre de termos de línguas locais e refletindo o que já dissera Luandino Vieira sobre o português ser, em Angola, um despojo de guerra, na afirmação da apropriação inusitada da língua portuguesa nesse contexto póscolonial e, sobretudo, de um ato de liberdade e não de passividade diante de um destino inevitável. (Sansone e Furtado, 2014, p. 286-287)

O que se conta e como se conta são intimamente ligados para criar essa utopia de futuro em seus escritos. A fala presente desde Luuanda do griot, um contador de histórias tradicional em toda África, também deixa o caminho preparado para que possamos perceber a presença de Angola.

E Angola existe nos relatos iniciais de seus musseques, no seu universo de infância, onde foi criado desde a chegada em Luanda. Em seus livros ao longo dos anos 60 e até se afastar da literatura momentaneamente nos anos 80, ele sempre conta histórias passadas nesses locais. Reforçando a noção de escrita das margens. Afinal, a escrita está na margem da colônia, só se escreve em português que não é a língua de todos, e o simples fato de ser colônia ela já está na margem em relação à metrópole. Luandino então coloca em sua escrita o status de subalterno, não ele, mas Angola.

Sua escrita vai reforçando esse sentido político da linguagem, do tornar o texto intraduzível como forma de resistência do subalterno. Da palavra enunciada só ser compreendida completamente por quem tem o domínio linguístico do registro falado no musseque. A mistura de quimbundo e português que não é conhecida fora de Angola. Esse hermetismo dá ao texto de Luandino uma capacidade de se destacar na produção. Luuanda, por ter conseguido isso, é dos seus livros mais premiados e lembrados até hoje. É um marco, um ponto inicial para sua obra.

Após seu exílio voluntário das letras, causado por um desconforto com os rumos tomados pela política em Angola após as primeiras eleições independentes - mais uma mostra de que, para ele, seu trabalho enquanto ativista e enquanto escritor são intimamente ligados, de que para ele, como para Rancière, política e arte são coisas diferentes e a mesma coisa, na medida em que são práticas que dizem respeito ao comum - Luandino volta a escrever como Kapapa. Nele começa a sair de seu ambiente consagrado, os musseques, e começa a falar de outra Angola, não a das periferias. 
A sua Angola resgata uma história que não é mais o presente enquanto ele escreve, não tem mais o tom de denúncia da opressão da colônia, mas sim o tom memorialista de um retorno à infância, da produção de algo novo a partir da morte. O menino é rebatizado de Kapapa pelo avô. Aquele que matou a arraia, o que ganhou da morte. Esse pequeno conto dá o tom do que viria depois. E de onde Luandino colocou a sua utopia, sua possibilidade de futuro.

$\mathrm{Na}$ trilogia, que parte do mesmo personagem que já vimos em Kapapa, que funciona então como uma espécie de alter ego do escritor, o que se esclarece aos poucos ao longo da trilogia. O Kene Vua, que é o Kapapa, que é Diamantinho, é Luandino nos contando as histórias de Angola. Falando aqui em um espaço em que estabeleceu ser fábula, em que estabeleceu que a memória dos fatos é tal como reconstituída em sua cabeça, Luandino se atém ao que lhe interessa e da forma que lhe interessa na história da guerrilha que criou a Angola de hoje. Como ele diz em entrevistas já citadas nesta dissertação, o quadro histórico lhe interessa para a criação dessa história de ficção.

Não existe a possibilidade de fabular fora do quadro histórico, quer dizer, a sua criação, pela força política que tem, depende da história de seu país. E a força política da sua criação está não só na história que é contada, mas também na forma como ela é contada, e na utilização feita do idioma, no caso o português. Toda literatura é política, mas cada literatura exerce a política à sua maneira. Em O Livros dos Rios e continuando com O Livro dos Guerrilheiros, Luandino trabalha a linguagem de seus livros em todo o seu potencial. Usa-a novamente como produtora de sentido e de possibilidades. Kene Vua tem parte da sua força na linguagem com que relata os acontecimentos. A autenticidade de cada um dos guerrilheiros também é sentida pela forma como falam e contam suas vidas. $\mathrm{Na}$ língua misturada de quimbundo em português que ocupa o espaço da marginalidade em Angola, mesmo hoje. Afinal, o português ainda é a língua oficial da nação angolana:

Angola é, de longe, o país em que o alcance do uso do português é mais transversal, percorrendo distintos grupos sociais e a geografia geral do país. Estamos de fato diante de um dos poucos países africanos em que mais de $50 \%$ da população usa cotidianamente a língua do Estado e das elites, o que singulariza o contexto nacional angolano. (Sansone e Furtado, 2014, p. 286) 
A opção pelo texto que mistura o quimbundo e o português, que gera necessidade de um glossário, de uma intermediação, é uma opção tão política quanto a da história que ele quer contar. Toda tradução é feita de escolhas políticas, e um texto que precisa de um glossário, de uma mediação, é um texto que parte dessa escolha política de precisar da tradução. Parte da escolha de não ser um texto rápido e digerível, de pedir a quem lê o tempo de entender e de buscar o que está lendo. E a manutenção dessa opção nessa nova trilogia é uma das questões que nos leva a acreditar, como quisemos mostrar, que a luta de Luandino pela sua utopia de um país livre e igualitário em Angola ainda não terminou.

Angola independente não é a Angola utópica com que ele e os da sua geração, de 50, sonharam. Ainda não é a Angola pela qual foram presos e ficaram anos no Tarrafal ou pela qual lutaram pelo meio dos rios. Como essa passagem do final d'O Livro dos Guerrilheiros nos mostra, Angola não se tornou a utopia de nação igualitária pretendida pelos guerrilheiros. E eles mesmos são em parte culpados disso:

- Não tens vergonha de andar numa chata?!...

- Tenho! disse eu. Mas é pro camarada general andar de iate. Senão, não dava!... O mar não cabia para os dois... E então o general Kimbalanganza, quando ouviu estas palavras, pôs uma sua má caradura mas entristeceu. Falou, quase calado, e eu senti que também ele não gostava ser nosso general, naquela hora:

- Kene Vua, meu kamba! Podes me tratar por tu... tuala kumoxi!...

«Mas não misturados...» pensei eu de atrever-lhe umas respostas dum camarada, um mulato sangazulo, escritor e meu amigo. Não deixei falar meu coração, calei. Recebi, no ar, a lata de cerveja que ele atirou-me borda fora. Agradeci, mas abrilhe como quem descavilha uma granada. Bebi a espuma gelada, queria muito varrer nas palavras emboscadas na minha garganta. Por isso, soletrei:

- Tenho de fazer meu neto. (Vieira, 2010)

O general tinha sido um dos companheiros de guerrilha de Kene Vua, seu chefe. E agora vive no iate. Vive do dinheiro que deveria ser compartilhado, para Kene Vua. Ele abre a cerveja como uma granada. A luta vai continuar, porque é preciso continuar a buscar a utopia, porque ela ainda não foi alcançada. $\mathrm{O}$ trabalho de Luandino com essa trilogia aponta para isso. As armas não são as mesmas porque o inimigo a ser combatido não é o mesmo.

Não se luta mais contra Portugal e seus desmandos. A luta contra uma mentalidade, uma Angola que perdeu a fé nas utopias e se tornou prática demais. 
Que permitiu que a desigualdade e as opressões ocorressem entre os seus, sem a necessidade de um colonizador. É preciso voltar e estudar o caminho para se poder voltar a lutar. E é por esse caminho que Luandino trilha. Volta e examina e nos dá a examinar - o que foi a guerrilha em seu país, o que aconteceu desde que ela começou. E antes até, como foi que Angola chegou até onde está.

De certa forma, se distanciando da denúncia clara feita em seus primeiros livros, em que a linguagem entrava como um complicador da compreensão do que se falava, mas o que estava sendo denunciado era algo evidente, nessa trilogia Luandino Vieira parece querer que o leitor entre em diálogo com o texto. Ele coloca as pistas do que está querendo dizer e deixa a nós a tarefa de descobrir os caminhos para compreender.

E podemos seguir as dicas, as homenagens e as citações - até autocitações, ou aqui uma homenagem a Pepetela , ali os personagens de Nós, os do Makulusu ou a rainha Njanda que existe ou também é fábula? Ao ler os livros da trilogia percebemos, talvez de forma diferente do que acontece em todos os livros anteriores do autor, a transformação da história fabulada contada em história que busca transformação. Porque nós enquanto leitores precisamos ser tocados e transformados para lermos a contento essa obra.

A luta continua, e é uma luta para que os generais não tenham tantos direitos sobre a vida dos Kene Vua. E é uma luta dentro de cada um também. De reler e reinterpretar. Voltando à questão do "real", a repetição do acontecimento é necessária para podermos elaborar o que advém dele e seguir para o próximo ponto do caminho. Essa estrutura do trauma como descrito por Foster, que citei anteriormente, faz parte da construção do "real" em Vieira. A trilogia nos fornece uma elaboração possível do que foi a guerrilha de Angola. Do que é Angola hoje, como se constituiu desde as lutas protoanticoloniais da rainha Njinga. É a partir dessa elaboração feita por ele que cada leitor pode construir sua elaboração. Pegando os pedaços como que de um quebra-cabeça e construindo algo a partir disso.

Não é um livro fácil, ele assume. É um livro que nos pede tempo. Tempo de elaboração. Como diz Luandino em entrevista, tudo é uma questão de tempo:

Isso ainda é elogiar o tempo. O tempo é o grande recolhedor de lixo, que anda de noite, a apanhar tudo, e nem sabe o que é que leva; mas o tempo irá ajudar nessa 
distinção da literatura de combate, que era literatura feita expressamente pelos seus autores com um fim político. Se os autores tinham na verdade algum talento, esse talento ficava expresso, e passada a urgência da época, se algum talento havia na construção literária, esse talento está lá. E se está lá, deve ser avaliado e reavaliado... e incluído ou não... (Vieira, 2010)

E o tempo é o que ele nos pede reiteradas vezes, a cada referência escondida em uma primeira vista. E o tempo é que Angola precisa para elaborar sua história e poder construir o seu futuro. 


\section{Referências bibliográficas}

ADICHIE, Chimamanda Ngozi. Vídeo. Disponível em: $<$ http://www.ted.com/talks/chimamanda_adichie_the_danger_of_a_single_story?1 anguage $=$ pt-br $>$. Acesso em 06 nov. 2014.

AGUAluSA, José Eduardo. Guerra e Paz em Angola. Conferência no dia 18 de Setembro de 2004, Festa Internacional de Literatura de Barcelona. Disponível em: <http://www.cccb.org/rcs_gene/agualusa-portu.pdf〉. Acesso em 07 nov. 2014.

Milagrário Pessoal. Rio de Janeiro: Língua Geral, 2010.

ALMEIDA, Sandra Regina Goulart de. Mediações contemporâneas: tradução cultural e literatura comparada. Gragoatá, v. 31, Niterói: UFF, 2012. p. 77-92.

ANDERSON, Benedict. Comunidades imaginadas: reflexões sobre a origem e a difusão do nacionalismo. São Paulo: Companhia das Letras, 2008.

ANTUNES, António Lobo. O Esplendor de Portugal. Rio de Janeiro: Rocco, 1999.

ARENDT, Hannah. Between Past and Future. Nova Iorque: The Viking Press, 1961.

BENJAMIN, Walter. A tarefa-renúncia do tradutor. Trad. Susana Kampf Lages. In: HEIDERMANN, Werner. (Org.). Clássicos da teoria da tradução. Florianópolis: UFSC, 2001.

BORGES COELHO, João Paulo. Da violência colonial ordenada à ordem póscolonial violenta: sobre um legado das guerras coloniais nas ex-colônias portuguesas. Disponível em: <http://www.lusotopie.sciencespobordeaux.fr/borges2003.pdf>. Acesso em 14 mar. 2015.

BRUM-DE-PAULA, Mirian Rose. O outro no (in)traduzível. Santa Maria: UFSM, PPGL-Editores, 2008.

CALVINO, Ítalo. Seis Propostas para o Próximo Milênio. São Paulo: Companhia das Letras, 1990. 
CHAVES, Rita. Angola e Moçambique - Experiência Colonial e Territórios Literários. São Paulo: Ateliê Editorial, 2005.

A Contemporaneidade Exige do Escritor um Compromisso com a Sua Própria Formação. Entrevista concedida à União dos Escritores Angolanos. Disponível em: <http://www.ueangola.com/entrevistas/item/412-acontemporaneidade-exige-do-escritor-um-compromisso-com-a-suapr\%C3\%B3pria-forma\%C3\%A7\%C3\%A3o>. Acesso em: 11 jan. 2015.

O livro dos rios de José Luandino Vieira. Disponível em: http://cartamaior.com.br/?/Editoria/Midia/\%27O-livro-dos-rios\%27-de-JoseLuandino-Vieira/12/12105>. Acesso em 12 fev. 2015.

DELEUZE, Gilles; GUATTARI, Félix. Kafka: Pour une Littérature Mineure. Paris: Les Éditions de Minuit, 1975.

DELEUZE, Gilles. O Abecedário de Gilles Deleuze. Transcrição integral do vídeo, para fins exclusivamente didáticos. Disponível em: <http://stoa.usp.br/prodsubjeduc/files/262/1015/Abecedario+G.+Deleuze.pdf >. Acesso em 13 mar. 2015.

EDMUNDO, Francisco Kulikolelwa. O nacionalismo militante em o "Livro dos rios", de José Luandino Vieira. Disponível em: <http://www.buala.org/pt/aler/o-nacionalismo-militante-em-o-livro-dos-rios-de-jose-luandino-vieira>.

Acesso em 12 fev. 2015.

ESTATUTO dos indígenas portugueses das províncias da Guine, Angola e Moçambique. Disponível em: <http://disruptiva.net/nodes/view/29>. Acesso em 14 mar. 2015.

FOSTER, Hal. The return of the real: the avant-garde at the end of the century. Massachusetts Institute of Technology. Massachusetts, 1996.

FOUCAULT, Michel. As palavras e as coisas. São Paulo: Martins Fontes, 2000.

La fonction politique de l'intellectuel. «Entretien avec Michel Foucault» Disponível em: 〈http://1libertaire.free.fr/MFoucault133.html〉.

GOULART, Audemaro Taranto. In: ABDALA JR, Benjamin; SCARPELLI, Marli Fantini. (Org.). Portos Flutuantes: trânsitos ibero-afro-americanos. São Paulo: Ateliê Editorial, 2004.

LABAN, Michel et al. Luandino: José Luandino Vieira e sua obra. Lisboa: Edições 70, 1980.

LEITE, Ana Mafalda. Literaturas Africanas e formulações pós-coloniais. Lisboa: Edições Colibri, 2003. 
LIENHARD, Martin. Situação Diglóssica e Narrativa Moderna em Angola. In: África, escritas literárias: Angola, Cabo Verde, Guiné-Bissau, Moçambique, São Tomé e Príncipe. Rio de Janeiro: Editora UFRJ/UEA, 2010.

LOURENÇO, Eduardo. A nau de Ícaro. São Paulo: Companhia das Letras, 2001.

MBEMBE, Achille. On the postcolony. University of California Press, Berkeley, Los Angeles, 2001.

As formas africanas de autoinscrição. Estudos Afro-Asiáticos. a. 23, n.1. Rio de Janeiro: Centro de Estudos Afro-Asiáticos/Universidade Cândido Mendes, 2001. Disponível em: $<\mathrm{http}: / / \mathrm{www}$.scielo.br/scielo.php?script=sci_arttext\&pid=S0101546X2001000100 $007 \& \operatorname{lng}=$ en\&nrm=iso\&tlng=pt $>$.

MORAES, Ana Martins de. Guimarães Rosa lido por africanos: impactos da ficção rosiana nas literaturas de Angola e Moçambique. Disponível em: $<$ http://www.buala.org/pt/a-ler/guimaraes-rosa-lido-por-africanos-impactos-daficcao-rosiana-nas-literaturas-de-angola-e-mocam>. Acesso em: 21 mar. 2015.

PESSOA, Fernando, Obra Poética em um volume. Rio de Janeiro: Companhia José Aguilar Editora, 1969.

PIRES LARANJEIRA, José Luís. Originalidade da Literatura Africana. Cadernos de Literatura, n. 3, Centro de Literatura Portuguesa da Universidade de Coimbra/INIC, out. 1979.

PIRES, José Cardoso. E agora. José? Lisboa: Publicações Dom Quixote, 1999.

PORTUGAL. Constituição Portuguesa, de 11 de abril de 1933.

RANCIÉRE, Jacques. A Partilha do Sensível, Estética e Política. Trad. Monica Costa Netto. São Paulo: Editora 34, 2009.

RIBEIRO, Margarida Calafate. De Rios e Guerrilheiros por José Luandino Vieira. In: CURY, Maria Zilda Ferreira; FONSECA, Maria Nazareth Soares. (Org.). África: dinâmicas culturais e literárias. Belo Horizonte: Editora PUC Minas, 2012.

RIVERA, Tânia. Guimarães Rosa e a Psicanálise: ensaios sobre imagem e escrita. Rio de Janeiro: Jorge Zahar, 2005.

ROSA, João Guimarães. "Primeiras Estórias". Rio de Janeiro: Editora Nova Fronteira, 1988.

Grande Sertão: veredas. Rio de Janeiro: Editora Nova Fronteira, 2006. 
SAlGADO, Maria Teresa; SEPÚlVEDA, Maria do Carmo. (Org.). Letras e Laços - África e Brasil. Rio de Janeiro: Editora Atlântica, 2000.

SANSONE, Lívio; FURTADO, Cláudio Alves. (Org.). Dicionário crítico das ciências sociais dos países de fala oficial portuguesa. Salvador: EDUFBA, 2014.

VEIGA, Luiz Maria. Via Atlântica, n.16, São Paulo: USP, dez/2009.

VIEIRA, José Luandino. Luuanda. São Paulo: Companhia das Letras, 2008.

Kapapa. Lisboa, Parque Expo 98, 1998.

De Rios Velhos e Guerrilheiros I. O Livro dos Rios. Alfragide: Editorial Caminho, 2006. (Kindle edition)

De Rios Velhos e Guerrilheiros II. O Livro dos Guerrilheiros. Alfragide: Editorial Caminho, 2009. (Kindle edition)

A força política da linguagem. Entrevista a Ubiratan Brasil para o jornal O Estado de São Paulo, 15 de março de 2015. Disponível em: $<$ http://cultura.estadao.com.br/noticias/geral,a-forca-politica-da-linguagem-imp,639999>. Acesso em: 12 fev. 2015.

Entrevista concedida à Alexandra Lucas Coelho, no jornal Público em 15 de maio de 2009. Disponível em: <http://www.publico.pt/politica/noticia/osanos-de-cadeia-foram-muito-bons-para-mim-1377921>. Acesso em 15 mar. 2015.

. Entrevista dada por José Luandino Vieira a Pires Laranjeira, em 1994, para a Universidade Aberta. Disponível em: 〈http://www.caminho.leya.com/pt/literatura/romance/luuanda/>. Acesso em 15 mar. 2015. 